FILOLOGIJA 69 Zagreb 2017.

\author{
Ana Šimić \\ Staroslavenski institut \\ Demetrova 11, HR-10000 Zagreb \\ ana.simic@stin.hr
}

UDK 811.163.42'374

811.163.1'374

https://dx.doi.org/10.21857/ygjwrcj8ey

Izvorni znanstveni članak

Primljen 30.IV.2017.

Prihvaćen za tisak 19.II.2018.

Uspomeni Nevenke Linarić

\title{
MIKROSTRUKTURA I ISTRAŽIVAČKI IZAZOVI OBRADE RJEČNIKA CRKVENOSLAVENSKOGA JEZIKA HRVATSKE REDAKCIJE
}

\begin{abstract}
Rječnik crkvenoslavenskoga jezika hrvatske redakcije ulazi u leksikografsku kategoriju rječnika razdoblja, podvrste povijesnoga rječnika. U radu su predstavljene posebnosti rječničkoga članka (četiri pisma i pet idioma) i njegova mikrostruktura koja obuhvaća ortografske i grafijske, gramatičke, semantičke, stilističke, distribucijske, međujezične, ilustrativne i uporabne podatke. Zahvaljujući sadržajnosti rječničkoga članka Riječnik je crkvenoslavenskoga jezika hrvatske redakcije primjenjiv i u daljnjim samostalnim ili komparativnim filološkim istraživanjima zadanoga korpusa. U drugom se dijelu rada promišljaju istraživački izazovi obrade Rječnika koji proizlaze iz činjenice da je riječ o prvoj leksikografskoj obradi hrvatskoga crkvenoslavenskoga jezika, književnoga idioma čiji tekstovi imaju latinske i starogrčke izvornike. Zbog toga nije rijetko da su obrađivaču katkada jasniji izvornici od prijevoda, što može omesti valjanu identifikaciju hrvatske crkvenoslavenske riječi. Osim oslanjanjem na latinske i starogrčke izvornike, leksikografova pristranost može biti potaknuta i oslanjanjem na sinkroniju, posebno kada obrađuje riječi prepoznatljiva oblika i naizgled prozirna značenja. Prevladavanje navedenih izazova omogućuje već samo postojanje svijesti o njima kao i trajno produbljivanje vlastitih lingvističkih kompetencija te timski rad.
\end{abstract}


Ana Šimić: Mikrostruktura i istraživački izazovi obrade Rječnika crkvenoslavenskoga...

FILOLOGIJA 69(2017), 99-128

\section{Uvod}

Povijesni ili historijski rječnik onaj je rječnik koji prati i predstavlja povijest vokabulara nekoga jezika, a istu funkciju ima i tzv. dijakronijski rječnik. ${ }^{1}$ Prema toj definiciji Rječnik crkvenoslavenskoga jezika hrvatske redakcije nije povijesni rječnik. Povijesni je, primjerice, Rječnik hrvatskoga ili srpskoga jezika (Jugoslavenska akademija znanosti i umjetnosti, 1880.-1976.). Leksikografska kategorija koja pobliže određuje Rječnik crkvenoslavenskoga jezika hrvatske redakcije jest tzv. rječnik razdoblja (eng. period dictionary) koji dokumentira rječničko blago određenoga razdoblja, a nerijetko se smatra i podvrstom povijesnoga rječnika. ${ }^{2} \mathrm{U}$ Rječnik crkvenoslavenskoga jezika hrvatske redakcije predstavljen je leksikografski opis hrvatskoglagoljskih tekstova crkvenoslavenskoga razdoblja, odnosno prvoga hrvatskoga književnoga idioma - hrvatskoga crkvenoslavenskoga. No osim povijesti hrvatskoga jezika, Rječnik pridonosi i saznanjima o povijesti prvoga slavenskoga književnoga jezika - starocrkvenoslavenskoga, čiji bi cjeloviti povijesni rječnik trebao obuhvaćati starocrkvenoslavenske (kanonske) tekstove, tekstove crkvenoslavenskih idioma srednjovjekovnoga razdoblja (tj. redakcija starocrkvenoslavenskoga) kao i onih novocrkvenoslavenskih. Valja primijetiti i da je s obzirom na neke svoje karakteristike Rječnik ipak srodan temeljnoj definiciji povijesnoga rječnika (vidi 3.5.).

\subsection{Odjeci Rječnika crkvenoslavenskoga jezika hrvatske redakcije}

Rječnik crkvenoslavenskoga jezika hrvatske redakcije dosada je ispisan na 1216 stranica obrojčenih arapskim brojkama, izdan je u 20 sveščića uvezanih u dva sveska (RCJHR1 2002; RCJHR2 2016), a u njegovoj je obradi, uređivanju i pripremanju za tisak dosada sudjelovalo više desetaka potpisanih suradnika, od kojih su većina bivši ili sadašnji zaposlenici Staroslavenskoga instituta u Zagrebu, izdavača i pokretača Rječnika. Rad je na Rječniku započeo mnogo prije izdavanja prvoga sveščića 1991. godine, pa se može reći da se kroz njegovu pripremu, obradu i izdavanje umnogome prelamala i povijest djelatnosti Staroslavenskoga instituta.

Da o važnosti Rječnika crkvenoslavenskoga jezika hrvatske redakcije, koji je ujedno i prvi rječnik neke redakcije starocrkvenoslavenskoga jezika, za slavistiku nema sumnji potvrđeno je i u prikazima Georga Holzera (»Es erübrigt sich, die Bedeutung dieses Werks für die Slavistik zu betonen:

\footnotetext{
1 Vidi Hartman, James 2002:38, 68; usp. Simeon 1969:310.

2 Hartman, James 2002:107. Usp. Simeon 1969:310. Ne čudi stoga ni što se rječnici koji su zapravo rječnici razdoblja nazivaju povijesnim rječnicima, kao npr. u Harambašić 2001.
} 
Ana Šimić: Mikrostruktura i istraživački izazovi obrade Rječnika crkvenoslavenskoga... FILOLOGIJA 69(2017), 99-128

Sie liegt auf der Hand.« Holzer 1996:318), Emilie Bláhove (»Již dosud vydaná část předvádí velice zajímavý materiál, přínosný jak pro studium církevní slovanštiny, tak i charvátštiny a slovanských jazyků v širších souvislostech.« Bláhova 1997:223) і Jasmine Grković-Mejdžor (»Стога је овај драгоцени речник несумњиво и од ширег значаја за палеославистику и словенску филологију у целини«, Грковић-Мејџор 2007:187). U svom је prikazu Holzer Rječnik nazvao i monumentalnim djelom, a za istom je sintagmom posegnuo i recenzent Rječnika Josip Bratulić. Osim njega, Rječnik je recenzirao i Johannes Reinhart koji je u svojoj ocjeni zabilježio: »U njegovu visoku znanstvenu razinu nema sumnje. To je djelo sigurno jedno od najizvrsnijih dostignuća hrvatske filološke, odnosno humanističkih znanosti uopće u zadnjim desetljećima «. ${ }^{3}$

Peter Rehder (2004:199) pak, koji o Rječniku govori kao o iznimnom i opsežnom jezičnom, književnom i kulturnopovijesnom pothvatu (»umfassende sprach-, literar- und kulturhistorische Großunternehmen«), nije propustio uočiti izazove koji stoje pred njegovim tvorcima žele li taj pothvat dovesti do kraja. Rječnik je, prema Rehderu, golemi znanstveni, tipografski i financijski izazov za uski krug visokospecijaliziranih i iznimno motiviranih suradnika (»Und das ist eine riesige wissenschaftliche, aber auch (satz)technische und finanzielle Herausforderung für den kleinen Kreis der hoch specialisierten und außergewöhnlich gut motivierten Mitarbeiterinen...«).

Ovaj je rad posvećen izazovu koji Rehder stavlja na prvo mjesto, onom znanstvenom. Kako se znanstveno promišljanje, između ostaloga, temelji na istraživačkoj djelatnosti, u radu će se ukazati na neke istraživačke izazove s kojima se suočavaju obrađivači i urednici Rječnika crkvenoslavenskoga jezika hrvatske redakcije. No prije toga predstavit će se ono zbog čega se s izazovima valja suočavati, a to je konačan rezultat obrade: rječnički članak, tj. njegove posebnosti, sadržajnost i primjenjivost u daljnjim istraživanjima zadanoga korpusa i jezičnoga razdoblja.

\section{2. Četiri pisma i pet idioma}

Jedna je od uočljivijih posebnosti Rječnika sadržana u tome da rječnički članak sadrži četiri pisma - uglatu glagoljicu, staru ćirilicu, latinicu i grčki alfabet - te pet jezičnih idioma - hrvatski crkvenoslavenski, hrvatski, engleski, starogrčki i latinski. Natuknica (lema) se u Rječniku obilježava dvaput: prvo uglatom glagoljicom, a onda i starom ćirilicom. Starom se

3 Obje su recenzije dostupne na Odjelu za Rječnik crkvenoslavenskoga jezika hrvatske redakcije (Staroslavenski institut u Zagrebu). 
ćirilicom bilježe morfološka obilježja u glavi članka (npr. genitivni nastavci za imenice, 1. i 2. lice prezenta za glagole i dr.), grafijske kratice natuknica te podnatuknice (subleme). Grčkim alfabetom se, jasno, bilježi starogrčki jezik. Latinica dominira rječničkim člankom jer se njome bilježi sve osim naslova, tj. normaliziranoga oblika natuknice i podnatuknica, i starogrčkoga. Hrvatski crkvenoslavenski primjeri, izvorno svi pisani uglatom glagoljicom, preslovljeni su na latinicu, suvremenu scripta franca, čime je rječnik dobio na komunikativnosti i pristupačnosti suvremenom korisniku koji ne mora biti vičan čitanju glagoljice.

Kada je o jezičnim idiomima riječ, rječničkim člankom dominira hrvatski crkvenoslavenski. Standardni hrvatski jezik služi za suvremenu identifikaciju značenja obrađene natuknice koje je onda prevedeno i na engleski jezik. Nakon toga navode se starogrčka i latinska istoznačnica ili bliskoznačnica, zato što su hrvatski crkvenoslavenski tekstovi prijevodni tekstovi, tj. nastali su prevođenjem latinskih i starogrčkih izvornika. ${ }^{4}$ Valja napomenuti da se ne navodi latinski i/ili starogrčki prijevod obrađene natuknice, nego paralelni leksem odnosno leksemi koji su u procesu prevođenja potencirali odgovarajući hrvatski crkvenoslavenski leksem. Jednostavno rečeno, odnos nije; polazna (hrvatska crkvenoslavenska) riječ $\rightarrow$ (latinski i/ili starogrčki) prijevod, nego je obratan; (hrvatski crkvenoslavenski) prijevod $\rightarrow$ (latinska i/ili starogrčka) polazna riječ.

Samo u slučajevima kada hrvatski crkvenoslavenski prijevodni tekstovi nisu vjerni predlošku ili kada predložak nije utvrđen, pa nije ni moguće navesti odgovarajuću latinsku riječ, obrađena se hrvatska crkvenoslavenska natuknica prevodi na latinski jezik, ali ne i na starogrčki. Kako bi čitatelj znao da je riječ o prijevodu, takva je prevedenica označena kurzivom.

Osim kao jedan od jezika rječničkoga članka, latinski je i njegov metajezik. Drugim riječima, latinskim je jezikom zabilježeno sve čime se opisuje obrađena natuknica, bilo da je riječ o tekstu ili kraticama. ${ }^{5}$

\footnotetext{
4 Naravno, to ne znači da su glagoljaši pred sobom uvijek imali latinske ili grčke predloške. Prijevodi su do njih dolazili i posredno, primjerice, preko starijih prijevodnih matica i tekstova. No unatoč tomu, kada god je poznat predložak nekom hrvatskom crkvenoslavenskom tekstu i ako je prijevod vjeran originalu, u Rječniku se navodi latinska i/ili starogrčka bliskoznačnica ili istoznačnica hrvatskoga crkvenoslavenskoga leksema.

${ }^{5}$ Popis latinskih kratica nalazi se u RCJHR1 2000:XLIV-XLV.
} 
Ana Šimić: Mikrostruktura i istraživački izazovi obrade Rječnika crkvenoslavenskoga... FILOLOGIJA 69(2017), 99-128

\section{Mikrostruktura}

Mikrostruktura nekoga rječnika odnosi se na unutarnji raspored i sadržaj rječničkoga članka. Riječ je o komentarima koji su u različitom opsegu vezani za oblik i značenje obrađene riječi. ${ }^{6}$ Različite vrste rječnika sadrže sve ili neke od sljedećih podataka: ortografske (pravopis, oblične inačice), fonetske (izgovor, naglasak), sintaktičke (vrsta riječi, kolokacije i sl.), morfološke (infleksija, derivacija, slaganje), semantičke (značenjske i smislene strukture), stilističke (različite stilističke oznake), distribucijske (geografska ili sociolingvistička distribucija, učestalost u korpusu), etimološke, uporabne, ilustrativne (verbalni i neverbalni primjeri) te međujezične (odnos s drugim idiomima). ${ }^{7}$

Rječnik crkvenoslavenskoga jezika hrvatske redakcije korisniku pruža sve navedene informacije osim fonetskih i etimoloških. Prve i nije moguće generirati iz korpusa jer je riječ o povijesnom idiomu. Fonetski je opis moguć u rječnicima suvremenih jezika, a kada je o povijesnim idiomima riječ, načelno je zamisliv za leksikografsku obradu izrazito mlađih povijesnih idioma, npr. onih u 20. st. kada su se stvorili tehnički preduvjeti za bilježenje zvučnoga zapisa. No, i u Rječniku postoje iznimke. Primjerice, za česticu že stoji podatak da je enklitička riječ (RCJHR2 2016:536). Za etimološke podatke postoje specijalizirani etimološki rječnici što Rječnik s obzirom na svoju svrhu nije. No to ne znači da se u njemu ne mogu naći neki etimološki podaci. Primjerice, u Rječniku se tuđice jasno označavaju pomoću latinskih opisa vox latina, vox graeca, vox hebraica i sl.

\subsection{Ortografski i grafijski podaci}

Ortografski se podaci iščitavaju iz normaliziranoga oblika natuknice u glavi rječničkoga članka. No valja istaknuti kako, ondje gdje ih ima, čitatelj nije uskraćen i za ostale grafijske karakteristike. O mogućim nenormaliziranim oblicima potvrđenima u korpusu obaviještava bilješka uvedena latinskim etiam koja se nalazi odmah ispod kanonskoga oblika. Kako se obrađena riječ u različitim oblicima pisala u srednjovjekovnim tekstovima, može se vidjeti i iz odabranih reprezentativnih priloženih primjera u korpusu koji čine glavninu tijela rječničkoga članka. Takvi su podaci, između ostaloga, dobrodošli i za povijesna istraživanja hrvatske fonologije.

Konačno, Rječnik sadrži i podatak je li se obrađena riječ u izvornim tekstovima kratila, što je jedna od najvažnijih i najzamjetljivijih osobina pismovne organizacije srednjovjekovnih tekstova, kako ističe M. Žagar

${ }^{6}$ Usp. Hartman, James 2002:94; Swanepoel 2003:46.

7 Vidi Swanepoel 2003:47-48. 
Ana Šimić: Mikrostruktura i istraživački izazovi obrade Rječnika crkvenoslavenskoga...

FILOLOGIJA 69(2017), 99-128

(2007:439). U slučaju da jest, navode se njezine kratice (uvedene latinskim abbreviatur, abbreviatum, in abbreviatione, abbrev. i sl.), a nerijetko i podatak o učestalosti upotrebe kratice (saepe, saepissime, tantum, persaepe).

\subsection{Gramatički podaci}

Ono što anglosaksonska lingvistika naziva sintaktičkim kategorijama odnosi se zapravo na vrste riječi. Taj je podatak u leksikografskim priručnicima u pravilu jedan od prvih koji se navodi nakon natuknice, ali se može naći i u tijelu članka ako natuknica ima nekoliko značenja ili različitih upotreba. Slično je i u Rječniku crkvenoslavenskoga jezika hrvatske redakcije. Osim oznake same kategorije riječi, korisniku su dostupni i ostali podaci koji ulaze u domenu morfosintaktičke identifikacije.

Za imenice, ukoliko su bile deklinabilne, navodi se nastavak $u$ genitivu jednine i rod, iz čega se može iščitati kojem je deklinacijskom razredu pripadala. Isto vrijedi i za vlastita imena koja dobiju i pobližu oznaku ako nisu antroponimi (npr. nom. propr. loci, montes, fluminis, montis, agri ...). Takve su oznake, očito, već u području semantičkih informacija. Osim toga, primjerice, olakšavaju leksikolozima potragu u leksičkoj analizi korpusa. Nedeklinabilne imenice označene su kraticom indecl. Pridjevi se navode $\mathrm{u}$ neodređenom obliku, a onima koji imaju i određeni oblik dometnut je nastavak -i. Posebno su obilježeni posvojni pridjevi (adj. poss.), zamjenički pridjevi (pron. adj.) te poimeničeni pridjevi (adj. subst.) ako su potvrđeni isključivo kao poimeničeni. No i inače, obrađivači moraju voditi računa da ne propuste zabilježiti primjere poimeničenja pridjeva unutar članka, što se također bilježi kraticom subst. Isto tako, ne smiju propustiti u članak unijeti primjere komparacije pridjeva (kratica comp. i superl.), jednako kao i priloga. Opisnim se prilozima u pravilu ne domeću kratice nikakvih drugih obilježja, dok se za ostale ipak daje nešto širi opis koji već ulazi u područje semantike (adv. num., adv. loci, adv. loci et temp., adv. mensurae i dr.). Glagoli su jedina vrsta riječi za koju ne postoji kratica kategorije riječi. Da je neka lema glagol, proizlazi iz dometnutih nastavaka za prvo i drugo lice prezenta te podatak o vidu, odnosno o tome je li glagol nesvršen, svršen ili dvovidan. Bilježe se i neke specifične ili isključive rekcije nekih glagola npr. beĉ́stvovati (RCJHR1 2000:148), varovati (RCJHR1 2000:271), dihati (RCJHR2 2016:296) i dr. Zamjenicama opseg gramatičkoga opisa ovisi o vrsti. Najdetaljnije se gramatički opisuju lične zamjenice kojima je dodana bilješka o licu i broju te su navedeni u korpusu potvrđeni padežni oblici. Većini drugih zamjenica donosi se oznaka vrste (pron. poss., pron. indef., pron. adj.), ali ne za sve, npr. eterb ${ }^{1}$ ili eliko ${ }^{2}$ (RCJHR2 2016:516-517, 475-476). Potonja je pak obilježena kao nedeklinabilna. 
Ana Šimić: Mikrostruktura i istraživački izazovi obrade Rječnika crkvenoslavenskoga... FILOLOGIJA 69(2017), 99-128

Nepromjenjive i funkcionalne riječi uglavnom imaju bilješku o kategoriji kojoj pripadaju. Veznici u glavi (rijetko) i tijelu članka (u pravilu) imaju kraticu koja identificira tip njihove funkcionalnosti (conj. causalis, conj. temp., conj. hypothetico-adiunctiva, conj. advers...), što je također podatak koji nije toliko morfosintaktički koliko uporabni. Za uzvike kao najmalobrojniju kategoriju riječi u zadanome korpusu u dosadašnjoj se obradi u tijelu članka nalazi podatak o poimeničenju (interj. subst.) ako do njega dođe. Prijedlozima (praep.) se redovito bilježi padežna rekcija. Rijetki primjerci koji padežne rekcije nemaju, poput prijedloga en (RCJHR2 2016:488), dobiju i objašnjenje zašto je izostala bilješka o rekciji (u konkretnom slučaju riječ je o tuđici). Upitnim česticama se u glavi članka dometne bilješka interrog., dok se ostalima bilješka o njihovoj funkcionalnoj naravi uglavnom nalazi u tijelu rječničkoga članka.

\subsection{Semantički podaci}

Kada je o semantici riječ, temeljna je definicija Rječnika crkvenoslavenskoga jezika hrvatske redakcije sintetička. Za razliku od opširnijih analitičkih definicija, sintetičke su pregnantne i najčešće dolaze u obliku sinonima. ${ }^{8}$ Gotovo da su pravilo u višejezičnim rječnicima u kojima se značenje polazne riječi semantički definira navođenjem istoznačnice ili bliskoznačnice iz drugoga jezika. Tako je i u Rječniku u kojem se hrvatska crkvenoslavenska natuknica semantički identificira navođenjem suvremenoga hrvatskoga i engleskoga te latinskoga i starogrčkoga sinonima. No o semantici korisnik može mnogo saznati i iz priloženih primjera iz korpusa.

Osim sintetičke definicije, nekim je natuknicama u Rječniku pridodana i kratka enciklopedijska natuknica, tj. ona koja definira referent, a ne značenje riječi. Takve će se definicije ponajprije naći u natuknicama koje su vlastita imena. ${ }^{9}$ Osim njih proširenu definiciju dobivaju i one manje poznate riječi stranoga podrijetla čije značenje nije transparentno iz suvremene hrvatske i engleske inačice te latinske i starogrčke, npr. dalmatika (RCJHR2 2016:253), dupleksb (RCJHR2 2016:380), efebêi (RCJHR2 2016:524) i dr.

Definicija se proširuje i upućivanjem na neku bibliografsku jedinicu koja tematizira obrađenu natuknicu, vidi npr. bartols (RCJHR1 2000:114) i vethosts (RCJHR1 2000:313).

\footnotetext{
8 Vidi Geeraerts 2003:86.

9 Jezični rječnici za razliku od enciklopedijskih u pravilu ne obrađuju sva vlastita imena, nego ona koja se odnose na osobe i mjesta tipična za povijest ili kulturu etničke grupe ili nacije čiji se jezik opisuje u rječniku te, u europskoj tradiciji, ona vezana za Bibliju ili mitologiju (Swanepoel 2003:50-51). U Rječniku crkvenoslavenskoga jezika hrvatske redakcije obrađena su i obradit će se sva imena potvrđena u korpusu.
} 
Ana Šimić: Mikrostruktura i istraživački izazovi obrade Rječnika crkvenoslavenskoga... FILOLOGIJA 69(2017), 99-128

Osim sintetičke i enciklopedijske definicije te priloženih primjera upotrebe obrađene natuknice $\mathrm{u}$ korpusu, semantička se obrada hrvatskih crkvenoslavenskih natuknica neizbježno suočava i s pojavom polisemije. U pravilu se polisemija u leksikografiji opisuje pomoću oznaka (bilješki) ili grupiranjem. ${ }^{10} \mathrm{U}$ Rječniku se nalaze oba tipa opisa. Od oznaka su najčešće fig. (figurative) i spec. (specialiter). Prva se odnosi na različite tipove prenesenoga značenja, dok druga upućuje na primjere u kojima se opće značenje specijaliziralo za neko posebno. Primjerice, leksem se doktorb u korpusu odnosi na crkvene naučitelje i to je u Rječniku uvedeno oznakom spec. (RCJHR2 2016:327-328). Katkada se neka posebna značenja uvode latinskim opisom in sensu, vidi npr. darb (RCJHR2 2016: 261), ili pomoću prijedloga de, npr. etiopiê (RCJHR2 2016:518). Grupiranje je značenja u rječničkome članku eksplicitno vidljivo upotrebom arapskih brojeva 1, 2, 3 ... (npr. blagodêt b u RCJHR1 2000:170-171), latiničnim slovima a), b), c) ... (npr. dobrêt u RCJHR2 2016:317-318) te novim uvučenim retkom (npr. godina u RCJHR2 2016:176-177) i njihovim različitim kombinacijama. Temeljna su značenja najčešće odvojena arapskim brojkama dok su nijanse temeljnih značenja označene latiničnim slovima ili uvučenim recima. ${ }^{11}$

Osim polisemije, Rječnik donosi informaciju i o semantičkom odnosu sinonimije. Na kraju rječničkoga članka ili odlomka članka posvećenom nekom od značenja nalazi se kratka bilješka $c f$. (confer) koja navodi na natuknice sa sličnim i bliskim značenjem.

Na hominimiju pak s nekom drugom ili više riječi ukazuje postojanje natpisanoga indeksa (superskripta) u obliku arapskoga broja na osnovnom obliku natuknice u glavi rječničkoga članka, v. npr. blagodêtelı ${ }^{1} \mathrm{i}$ blagodêtels ${ }^{2}$ (RCJHR1 2000:169), vračb ${ }^{1}$ i vračb ${ }^{2}$ (RCJHR1 2000:563), žrêti ${ }^{1}$ i žrêti ${ }^{2}$ (RCJHR2 2016:582).

\subsection{Stilistički podaci}

Neki su od stilističkih podataka u rječničkom članku navedeni u sklopu netom predstavljenih semantičkih. Najčešća stilistička oznaka u Rječniku je fig. Ona se odnosi na različite nijanse konotacije koje neka riječ u korpusu može imati. Neke su od njih potvrđene isključivo s prenesenim značenjem, npr. vrênie, vshlaždenie, gorko, dvoêzičbnb, želêzce i dr. (RCJHR2 2016:8, 70, 191, 273, 541). Ako je preneseno značenje transparentno, oznaka fig. dolazi samostalno i nakon nje se navode primjeri upotrebe. No nije rijetkost da biva dopunjena latinskim opisom, npr. visokosts (RCJHR1 2000:447) i

\footnotetext{
10 Vidi Geeraerts 2003:85-86.

11 Usp. Geeraerts 2003:86. Latiničnim slovima su grupirani i različiti referenti u natuknicama koje su vlastita imena, npr. grêgorii (RCJHR2 2016:277).
} 
Ana Šimić: Mikrostruktura i istraživački izazovi obrade Rječnika crkvenoslavenskoga... FILOLOGIJA 69(2017), 99-128

deĉi (RCJHR2 2016:287), ili potpunim opisom sa suvremenom hrvatskom i engleskom te latinskom i starogrčkom bliskoznačnicom, npr. drbžati (RCJHR2 2016:369) i žestokb (RCJHR2 2016:549). Nije neobično da se pod oznakom fig. nalaze kolokacije, vidi npr. dolu i dolv (RCJHR2 2016:328, 329). Kod glagola se može dogoditi da je preneseno značenje povezano s povratnom inačicom, što se označava kao refl. fig., npr. u obradi natuknice emati (RCJHR2 2016:486). Osim toga, preneseno se značenje katkada veže i s određenom rekcijom glagola koja se onda također navodi, vidi npr. dihati (RCJHR2 2016:296).

Obrađivači ponekad pobliže definiraju tip figurativnosti, pa se u Rječniku mogu naći podaci o metonimijskom (meton.), npr. vrbsta (RCJHR1 2000:567) i erusolims (RCJHR2 2016:508), i metaforičnom prijenosu značenja, npr. dvoustatb (RCJHR2 2016:277), dragb (RCJHR2 2016:354).

\subsection{Distribucijski podaci}

Korpus Rječnika crkvenoslavenskoga jezika hrvatske redakcije ekscerpiran je na temelju šezdeset i šest (66) glagoljskih izvora, a njihov se broj po potrebi i proširuje (vidi RCJHR1 2000:XXXI-XXXVI). ${ }^{12}$ Ponajprije je riječ o rukopisnim kodeksima i fragmentima kodeksa, dok su oni tiskani manjina (npr. Baromićev brevijar i senjski Ritual tiskan s knjižicom Meštrija od dobra umrtija). Vremenski raspon koji obuhvaća zadani korpus kreće se od prve stranice Kijevskih listića (11.-12. st.) do Fatevićeva zbornika duhovnoga štiva (1617.). Ipak, sadržajno su najzastupljeniji rukopisi 14. i 15. stoljeća, zlatnoga doba glagoljaštva u Hrvatskoj. U Popisu su izvora (RCJHR1 2000:XXXI-XXXVI) izvori grupirani kao fragmenti $(F g)$, misali $(M)$, brevijari $(B r)$, psaltiri $(P s)$, rituali (Rit) i zbornici (C).

Obrada svake natuknice u Rječniku podrazumijeva i distribucijske podatke vezane za zastupljenost $\mathrm{u}$ korpusu. Distribucijski podaci nalaze se ispod glave članke, točnije, slijede nakon normaliziranoga oblika natuknice te osnovnih gramatičkih i grafijskih podataka (ako ih ima). Ako na mjestu predviđenom za distribucijske podatke stoji occurit saepe, saepe ili saepissime, to znači da je obrađena riječ obilno potvrđena u svim prethodno navedenim grupama izvora. Kada tomu nije tako, navode se kratice izvora u kojima je riječ potvrđena. U slučaju da je, primjerice, potvrđena u većini ili u svim brevijarima, bilježi se samo oznaka Br. U suprotnom, nabrajaju se poimence kodeksi o kojima je riječ. To vrijedi i za sve ostale skupine izvora. Kada je o brevijarima riječ, bilježi se i ako je natuknica potvrđena u kalendarima. Kada je pak o Fraščićevu psaltiru riječ, posebno se naznačuje ako

\footnotetext{
12 Više o izvorima vidi Nazor 1963. i 1997.
} 
Ana Šimić: Mikrostruktura i istraživački izazovi obrade Rječnika crkvenoslavenskoga... FILOLOGIJA 69(2017), 99-128

je riječ potvrđena samo u komentaru psaltira.

Po potrebi, kada se uoči pravilnost, navodi se i koji su grafijski oblici potvrđeni u kojim izvorima, v. npr. bez (RCJHR1 2000:120), vstati (se) (RCJHR2 2016:57) i vsêêti / vsêti (RCJHR2 2016:78). Slično tomu, ako je neko od značenja obrađene natuknice zabilježeno samo $u$ jednoj od ranije navedenih skupina izvora, korisnik neće biti uskraćen za taj podatak, v. npr. glumiti se (RCJHR2 2016:165) i gora (RCJHR2 2016:186). Isto vrijedi i za pojavnost kada je neka natuknica, njezina podnatuknica ili neko od značenja potvrđeno isključivo u određenim tekstovima, npr. Tužaljkama proroka Jeremije, psalmima, nekom apokrifu - vidi alêps (RCJHR1 2000:46), blagoizvoliti (RCJHR1 2000:142), zakhêi / zakhei (RCJHR2 2016:631) - ili vrsti tekstova, npr. molitvama - blizb (RCJHR1 2000:194), zaodêti (RCJHR2 2016:637).

Na navedenim se distribucijskim podacima mogu temeljiti različita leksikološka istraživanja i ona su relevantan pokazatelj povijesti određene riječi kao i njezina mjesta u ukupnoj povijesti hrvatskoga crkvenoslavenskoga, hrvatskoga i uopće slavenskih jezika. Povijesnom leksikologu mnogo će govoriti podatak je li neka riječ potvrđena u svim skupinama zadanih glagoljskih izvorima ili samo u nekima. Sadržajan je i podatak u kojim je izvorima potvrđena. S obzirom na nastanak kodeksa i njegovu tradiranost nije isto ako je potvrđena u Fraščićevu psaltiru i/ili Pariškome zborniku.

Osim prethodno navedenih kvalitativnih distribucijskih podataka, Rječnik donosi i one kvantitativne. O tome govori oznaka exh. (exhaustum) koja se prilaže natuknici ili nekom od njezinih značenja čije su potvrde, tj. primjeri u korpusu iscrpno preneseni, tj. preneseni su svi. Načelno se $u$ obradi to događa kada je neka riječ ili pojedino njezino značenje potvrđeno do deset puta u korpusu. Oznaka exh. bilježi se pri samome kraju rječničkoga članka odnosno semantičkoga odlomka unutar članka. U rječničkom se članku mogu naći i podaci o približnoj kvantitativnost, odnosno učestalosti. Tako se, primjerice, za natuknicu veliko navodi da je rijetko potvrđena u berevijarima, ali češće u zbornicima (RCJHR1 2000:291).

Konačni je pak podatak u rječničkom članku također vezan za distribuciju, ali više ne za onu vezanu za korpus Rječnika, nego za korpuse drugih relevantnih rječnika. Točnije, donosi se podatak o tome je li natuknica potvrđena, tj. obrađena u Slovníku jazyka staroslověnského (1966.-1997.), najopsežnijem rječniku starocrkvenoslavenskoga jezika i crkvenoslavenskih idioma, Miklošičevu Lexiconlinguae slovenicae veteris dialecti (1862.-1865.) te $\mathrm{u}$ Rječniku hrvatskoga ili srpskoga jezika (tzv. Akademijinu rječniku, 1880.-1976.) koji je povijesni rječnik, između ostalih, i hrvatskoga jezika. ${ }^{13}$ Premda

${ }^{13}$ Ova su tri rječnika označena kraticama $S, M$ i A, koje se zajedno, pojedinačno 
Ana Šimić: Mikrostruktura i istraživački izazovi obrade Rječnika crkvenoslavenskoga... FILOLOGIJA 69(2017), 99-128

Rječnik crkvenoslavenskoga jezika hrvatske redakcije u uvodu nije bio definiran kao povijesni rječnik u užem smislu riječi, činjenica da korisnik može vidjeti je li neka natuknica potvrđena u najstarijem posvjedočenom slavenskom jeziku, starocrkvenoslavenskom, te u povijesnom korpusu južnoslavenskoga jezika koji obuhvaća razdoblja mlađa od hrvatskoga crkvenoslavenskoga mnogo govori o njezinu povijesnom dosegu i rasprostranjenosti.

\subsection{Ilustrativni podaci}

U Rječniku se natuknica opisuje i navođenjem primjera iz korpusa. Upravo primjeri čine temeljni sadržaj rječničkoga članka. Budući da je korpus temeljen na glagoljskim izvorima od kojih većina nije izdana u preslovljenom (transliteriranom) obliku, Rječnik je u velikom broju slučajeva prva suvremena i preslovljena objava drevnih srednjovjekovnih redaka.

Navedeni se primjeri identificiraju navođenjem izvora i mjesta $u$ glagoljskom izvoru (broj lista i stupca). Ako je riječ o biblijskom tekstu, domeće se kratica biblijske knjige i retka. Kada je citirani primjer potvrđen u više izvora, onda se i to bilježi, ali se ne ponavlja cijeli primjer, nego samo oblik natuknice kada je drukčiji. Osim toga, bilježi se i ako je u nekom od izvora prijevod drukčiji od obrađene natuknice.

Ako je za primjere utvrđen latinski i/ili starogrčki izvornik, tj. latinska i/ili starogrčka inačica, onda se one navode nakon hrvatskoga crkvenoslavenskog primjera. Ako ih nema, to može značiti i da u korpusu postoji neka latinska i/ili starogrčka inačica dotičnoga teksta, ali je anizomorfizam između prijevoda i predloška prevelik da bi inačica primjera u predlošku bila relevantna za temeljni leksikografski opis.

Kada je riječ o izboru primjera, kako su istaknuli urednici prvoga sveska Rječnika Biserka Grabar, Franjo Većeslav Mareš i Ivana Mulc, vrijedi sljedeće:

»Izabiru se takvi primjeri koji će najbolje objasnili prvenstveno sva značenja riječi, njezin lik u rukopisima različitih razdoblja, različitoga geografskog i genealoškog podrijetla i različitoga sadržaja. Primjerima se takoder dokumentiraju sintaktičke, frazeološke, te zanimljive fonetske, morfološke, kao i pravopisne pojave.« (RCJHR1 2000:XV).

Korisniku Rječnika bit će dobrodošla činjenica da su u primjerima kratice razriješene i da je uz slovo koje ima brojevnu vrijednost ta brojevna vrijednost identificirana dometnutom arapskom brojkom u zagradi. Osim toga, ondje gdje je potrebno, objašnjava se na što se pojedina riječ odnosi.

ili u kombinacijama nalaze na dnu rječničkoga članka. Ako obrađena natuknice nije potvrđena ni u jednom od navedenih rječnika, bilježi se znak $\varnothing$. 
Ana Šimić: Mikrostruktura i istraživački izazovi obrade Rječnika crkvenoslavenskoga...

FILOLOGIJA 69(2017), 99-128

Primjerice, kada iz priloženoga primjera nije jasno što je subjekt, on se domeće u zagradi uveden kraticom sc., vidi npr. ejup'taiskb (RCJHR2 2016:529). Za pogreške se u glagoljskom prijepisu, također ondje gdje je to potrebno za razumijevanje, domeće ispravan oblik u zagradi uveden latinskim pro, vidi npr. adamovb (RCJHR1 2000:23) i bljudva (RCJHR1 2000:202). Parafraze se biblijskih tekstova također identificiraju pomoći kratice $c f$. nakon koje slijedi kratica biblijskoga teksta o kojem je riječ, vidi npr. vniti (RCJHR1 2000:507).

Zbog svega navedenoga ilustrativni su podaci u rječničkom članku Rječnika crkvenoslavenskoga jezika hrvatske redakcije referentno i dostupno polazište za daljnja jezična istraživanja zadanoga korpusa koja ne moraju imati veze ni s leksikografijom ni s leksikologijom.

\subsection{Međujezični podaci}

Hrvatska je srednjovjekovna književnost, pa tako i njezina najvažnija sastavnica - ona glagoljska - prijevodna književnost. Kada tekstove nisu prepisivali iz naslijeđenih ćirilometodskih književnih matica, glagoljaši su na hrvatski crkvenoslavenski prevodili latinske tekstove ili su prema latinskim tekstovima redigirali neke ranije naslijeđene (npr. one biblijske). Osim latinskoga, jezik je izvornika bio i starogrčki. Zbog toga će proučavanje hrvatske crkvenoslavenske pismenosti biti dobrodošlo različitim traduktološkim istraživanjima, ali i onim lingvističkim komparativne i/ili tipološke naravi. Pri tome je, zbog međujezičnih podataka koje donosi ,Rječnik crkvenoslavenskoga jezika hrvatske redakcije neizbježno polazište.

Glavninu međujezičnih podataka unutar rječničkoga članka čini odnos hrvatskoga crkvenoslavenskoga s latinskim i starogrčkim jezikom, počevši od definicije natuknice (s navođenjem latinske i starogrčke paralele) pa do primjera iz korpusa koji se navode (praćeni latinskom i starogrčkom inačicom). Po potrebi se naznačuje i učestalost prevođenja neke latinske odnosno starogrčke riječi hrvatskom crkvenoslavenskom, vidi npr. bo (RCJHR1 2000:204).

Osim toga, u rječničkom članku mogu se naći i druge prevoditeljske zanimljivosti. Primjerice, nije rijetkost da se određeni primjer(i) upotrebe nekoga leksema $\mathrm{u}$ korpusu ne uklapaju u njegovo temeljno značenje ili neko od temeljnih značenja. Oni se također uključuju u obradu, a najčešće su uvedeni latinskim pro ('za') nakon kojega slijedi latinska i/li grčka riječ koju prevodi dotična natuknica, vidi npr. grêhı (RCJHR2 2016:229). Takvi su primjeri zanimljive potvrde prijenosa značenja, npr. za latinski se professio u korpusu upotrijebio i hrvatski crkvenoslavenski abits (RCJHR1 2000:6), za catholicus pridjev bogoljubьnь (RCJHR1 2000:209), za Israëlitae et- 
Ana Šimić: Mikrostruktura i istraživački izazovi obrade Rječnika crkvenoslavenskoga... FILOLOGIJA 69(2017), 99-128

nik nešto užega značenja erusolimlane (RCJHR2 2016:507) i dr.

Izvajaju se i neke posebnosi u prevođenju. Primjerice, u rječničkom članku posvećenom prijedlogu bez navodi se kako se hrvatskim crkvenoslavenskim prijedložnim izrazom s prijedlogom bez prevode starogrčki leksemi s predmetkom $\dot{\alpha}$ - (privativno alfa) te latinski leksemi s predmecima in-, a- i ex- (RCJHR1 2000:120). Zbog toga takvi primjeri nisu obrađeni pod natuknicom $b e z$, nego u rječničkim člancima posvećenim imenskim riječima unutar takvih prijedložnih izraza.

Obrađivači u rječnički članak unose i bilješku o pogrešnom prijevodu (s metajezičnim opisom translatio erronea, npr. vsilati (RCJHR1 2000:22)), neodgovarajućem prijevodu (s opisom translatio minus apta, translatio non satis apta, translatio corrupta, npr. vitežstvo (RCJHR1 2000:457), žetvbno (RCJHR2 2016:551), elkakains (RCJHR2 2016:483)), slobodnijem prijevodu (s opisom translatio liberior, npr. vzdarenie (RCJHR1 2000:363), vskorê (RCJHR2 2016:29), doslovnom ili mehaničkom prijevodu (s opisom poput per translationem ad litteram, translationes mechanicae, npr. više (RCJHR1 2000:463), zakons (RCJHR2 2016:627)).

Kada je riječ o pogrešnom prijevodu, ondje gdje je to moguće, bilješci o pogrešci dodaje se pojašnjenje razloga njezina pojavljivanja. U pravilu je riječ o tome da je došlo do zamjene dviju fonološki sličnih riječi jezika izvornika, pa je upotrijebljena pogrešna hrvatska crkvenoslavenska riječ. Primjerice, leksem je vethosts 'starina, starost', kojim se prevodio latinski sinonim vetustas, jednom potvrđen za latinski veritas 'istina' (RCJHR1 2000:313). Više je puta pak grizenie, kojim se prevodio latinski sinonim morsus, upotrijebljeno za latinski morbus 'bolest' (RCJHR2 2016:216). Premda se takvi slučajevi katkada pripisuju prevoditelju (s metajezičnim opisom interpres slavicus ... confudit / commutavit), ne valja isključiti ni mogućnost da je pogreška postojala već i u latinskom predlošku ili je on možda bio previše oštećen da bi glagoljaš ispravno pročitao riječ. Vjerojatno je zbog toga u Rječniku učestalije da se bilješka o zamjeni navodi bez spominjanja prevoditelja, a najčešće je uvedena opisom per commutationem ..., v. npr. bolêz'nb (RCJHR1 2000:221), brazditi (RCJHR1 2000:228), vžizati (RCJHR1 2000:327), dvornosts (RCJHR2 2016:276), edinako (RCJHR2 2016:444) i dr.

Kao što je ranije rečeno, u rječničkom članku Rječnika crkvenoslavenskoga jezika hrvatske redakcije zrcali se i odnos hrvatskoga crkvenoslavenskoga sa suvremenim hrvatskim i engleskim jezikom (u temeljnoj definiciji). Osim toga, ovisno o tome nalaze li se na kraju članka oznake S (Slovník jazyka staroslověnského), M (Miklošičev Lexicon linguae slovenicae veteris dialecti) i A (Akademijin Rječnik hrvatskoga ili srpskoga rječnika), korisnik može steći sliku o odnosu hrvatskoga crkvenoslavenskoga sa starocrkvenoslavenskim i 
Ana Šimić: Mikrostruktura i istraživački izazovi obrade Rječnika crkvenoslavenskoga... FILOLOGIJA 69(2017), 99-128

ostalim crkvenoslavenskim idiomima, kao i s kasnijim razdobljima u povijesti hrvatske pismenosti.

\subsection{Uporabni podaci}

Komentar o uporabnim (pragmatičnim) podacima ostavljen je za kraj jer se mnogo takvih podataka prožima s prethodno već opisanim podacima sadržanima u članku Rječnika crkvenoslavenskoga jezika hrvatske redakcije.

Način kraćenja neke riječi u korpusu, kao dio njezina grafijskoga predstavljenja, govori o grafijskoj uporabi te riječi. Gramatičke podaci u glavi članka koji proširuju usko gramatičku identifikaciju (što se posebno odnosi na funkcionalne riječi: veznike, prijedloge, uzvike i čestice) odnose se na uporabu obrađene riječi kao i njihovi opisi unutar članka. Semantičkostilističke oznake fig. i spec. također govore o uporabi. Isto vrijedi i za distribucijske podatke o čestotnosti, kvantitativnoj (o čemu govori oznaka exh.) ili kvalitativnoj (primjerice, ako je neka riječ učestala u određenom tipu tekstova, npr. molitvama). Ilustrativni su podaci zapravo implicitna metoda opskrbljivanja rječnika pragmatičkim podacima, ${ }^{14}$ a o uporabi neke riječi mnogo govore i prethodno opisani međujezični podaci, pogotovo oni vezani za opis prijevodnih sklonosti, obrazaca i pogreški.

U leksikografiji se podaci o pragmatici uglavnom prenose preko različitih oznaka (eng. label). Najčešće su to jednorječnice ili kratice koje upućuju na određeno ograničenje u upotrebi neke riječi s obzirom na vrijeme, prostor i ostale komunikacijske okolnosti. ${ }^{15}$ Osim prethodno navedenih, $\mathrm{u}$ Rječniku nije rijetka pojava ugledati oznaku liturg. koja govori da se neka riječ upotrebljavala u liturgijskim obredima ili opisima liturgijskih obreda. Upotreba u liturgiji mogla je biti isključiva upotreba nekoga leksema, primjerice, dopêti i doreĉi (RCJHR2:239), ili jedna od mogućih, npr. vinbnı (RCJHR1 2000:442), vspominanie (RCJHR2 2016:46). Moguće je i da neka podnatuknica (sublema), tj. kolokacija bude vezana za liturgijsku upotrebu, npr. vspêti misu (RCJHR2 2016:46), nedêlê gluha(ê) (RCJHR2 2016:166). Kratica liturg. može doći zajedno s kraticom term. (terminus) ili techn. (technicus), npr. alleluê (RCJHR1 2000:43), godinonı (RCJHR2 2016:177). Te dvije oznake ne dolaze samostalno, nego zajedno ili s liturg. ili s nekim dodatnim latinskim objašnjenjem, vidi npr. vladič'stvie i vladič'stvo (RCJHR1 2000:476-447), čin uliêniê (pod vliêniê / uliêniê RCJHR1 2000:487).

Osim ranije navedenih, u Rječniku se nalaze i drugi podaci vezani za čestotnost, odnosno za manju ili nižu učestalost oblika ili funkcije neke rije-

\footnotetext{
14 Vidi Burkhanov 2003:107.

15 Vidi Burkhanov 2003:105.
} 
Ana Šimić: Mikrostruktura i istraživački izazovi obrade Rječnika crkvenoslavenskoga... FILOLOGIJA 69(2017), 99-128

či. Ključna je oznaka pri tome raro ('rijetko'). Primjerice, vzdaši kao drugo lice prezenta glagola vzdati u korpusu je rijetko potvrđen oblik. Učestaliji je vzdasi (RCJHR1 2000:363).

Na uporabu se neke riječi odnose i pogreške o uporabi, bilo da su nastale u prijepisu glagoljskoga kodeksa bilo u prijevodu, o čemu je već bilo riječi. Na pogreške u prijepisu unutar ilustrativnih primjera najčešće govori dometnuta oznaka (sic!) ('tako!') koja upućuje korisnika na to da za neočekivan oblik riječi (koja neposredno prethodi oznaci) nije odgovoran obrađivač, nego glagoljski pisar. Nije rijetkost da su neke od tih pogrešaka stvarale komičan učinak, primjerice umjesto se estb p(a)vlb iže gl(a)si vbzapilb estb nebu, kako stoji u IV. vrbničkom brevijaru, pisar je VI. vatikanskoga brevijara upotrijebio složeni glagolski oblik v'napili est' (obrađeno pod v'zpiti RCJHR1 2000:418). Ovakav tip pogreški, koje nisu samo grafijske, nego i konceptualne (premda potencirane sličnim fonološkim inventarom dviju riječi), govore o potencijalu psiholingvističkih proučavanja pogreški u jeziku.

Grafijske i konceptualne su i greške nastale zamjenom riječi zbog njihova sličnoga fonološkoga sastava. U prevođenju bi se zamijenile dvije starogrčke ili latinske riječi, pa je i hrvatski crkvenoslavenski prijevod bio pogrešan. O tome je bilo riječi u prethodnom potpoglavlju. U prijepisu pak s jednoga kodeksa u drugi zamjenjivale su se hrvatske crkvenoslavenske riječi. Takve se zamjene najčešće uvode latinskim opisima lectio erronea pro, erronee pro, per errorem pro, per commutationem, commutatum cum i sl., vidi bdêti (RCJHR1 2000:119), varovati (RCJHR1 2000:271), bezbožbno (RCJHR1 2000:124), vzvêĉenie (RCJHR1 2000:353), eter ${ }^{1}$ (RCJHR2 2016:517), gorêti (RCJHR2 2016:196), žetva (RCJHR2 2016:551), bezvêstons (RCJHR1 2000:125), eda (RCJHR2 2016:442) i dr.

O uporabi neke riječi govori i podatak o čvršćim spojevima riječi, odnosno kolokacijama. One se u Rječniku crkvenoslavenskoga jezika hrvatske redakcije ponajviše uvode kao podnatuknice (subleme), odnosno nalaze se unutar rječničkoga članka jednoga od članova kolokacije, v. npr. blagodêtıno (RCJHR1 2000:171), blizb (RCJHR1 2000:194), veĉi (RCJHR1 2000:318), dlbžbno (RCJHR2 2016:303), dbnı (RCJHR2 2016:391) i dr. Subleme se bilježe u normaliziranom obliku starom ćirilicom, a često su uvučene u novi redak. Nije rijetkost ni da sublemi prethodi latinski opis in iunctione s bilješkom o učestalosti (solum, tantum, persaepe, sepissime...), npr. avreliêns (RCJHR1 2000:16), domovits (RCJHR2 2016:334), edins / edina / edino (RCJHR2 2016:456). To se može očekivati kada je natuknica često ili isključivo potvrđena u određenoj kolokaciji. Kolokacije s glagolima dati i daêti pak razvrstane su i uvedene prema latinskoj paraleli (RCJHR2 2016:264-265, 268). 
Ana Šimić: Mikrostruktura i istraživački izazovi obrade Rječnika crkvenoslavenskoga... FILOLOGIJA 69(2017), 99-128

Zaključno se može reći kako ukupnost sadržajnih podataka kojima pregnantno raspolaže rječnički članak Rječnika crkvenoslavenskoga jezika hrvatske redakcije govori mnogo o jezičnom bogatstvu i posebnostima glagoljskih tekstova crkvenoslavenske provenijencije čineći Rječnik referentnim, reprezentativnim i nezaobilaznim polazištem za iščitavanje, razumijevanje i daljnje istraživanje srednjovjekovne hrvatske pismene i književne prakse. Osim toga, informativnost rječničkoga članka govori mnogo i o vremenu, trudu i znanju uloženom u njegovo sastavljanje. Nešto će više o tomu biti riječi u drugom dijelu ovoga rada koji je posvećen nekim od izazova s kojima se u izradi Rječnika suočavaju njegovi obrađivači i urednici.

\section{Istraživački izazovi obrade Rječnika crkvenoslavenskoga jezika hrvatske redakcije}

4.1. Osnovni izazov s kojim se susreću obrađivači i urednici Rječnika crkvenoslavenskoga jezika hrvatske redakcije jest činjenica da pred sobom imaju neobrađen i uglavnom nepoznat jezični materijal. Oni su ti koji moraju stvoriti prvu i osnovnu referentnu točku za razumijevanje hrvatskoga crkvenoslavenskoga jezika potrebno svima onima kojih se tiču tekstovi njime napisani, a to nisu samo filolozi, nego i medievisti različitih profila, književni teoretičari i povjesničari, teolozi i liturgičari, povjesničari umjetnosti i dr. Budući da se valjani opis jezika sastoji od popisa (jezičnih jedinica) i propisa (pravila o njihovu kombiniranju), kada je o hrvatskom crkvenoslavenskom riječ, Rječnik crkvenoslavenskoga jezika hrvatske redakcije zadužen je za popis. ${ }^{16}$ Njegovi rječnički članci predstavljaju nove i nepoznate, ili barem ne $u$ dostatnoj mjeri poznate, povijesne lingvističke podatke.

Ipak, valja postaviti i pitanje: postoji li građa ili rječnici koji njemu mogu biti referentnom točkom?

Novija hrvatska filologija zasada nije iznjedrila povijesni rječnik hrvatskoga jezika. Korpus je Rječnika hrvatskoga ili srpskoga jezika (1880.-1976.), koji je nastajao u okrilju ondašnje Jugoslavenske akademije znanosti i umjetnosti, sadržavao i povijesne hrvatske tekstove, od kojih je glagoljskih deset. ${ }^{17}$

\footnotetext{
16 Za propis se 2014. pobrinula na Staroslavenskom institutu dugo planirana i stvarana gramatika Hrvatski crkvenoslavenski jezik (HCSJ 2014). U Uvodu te gramatike autori ističu: »Bez kartotečne građe prikupljenje i sastavljane za izradu Rječnika i fototeke koja sadrži kopije gotovo svih hrvatskoglagoljskih kodeksa koji su razasuti po knjižnicama i zbirkama širom svijeta izrada ove gramatike ne bi bila moguća.« (HCSJ 2014:8).

17 Riječ je o Krčkom (Vrbničkom) statutu (1388.), Reguli svetoga Benedikta (14. st.), Kolunićevu zborniku (1486.), Ivančićevu zborniku (14. -15. st.), senjskim izdanjima; Spovid općena (1496.), Naručnik plebanušev (1507.), Korizmenjak (1508.), Mirakuli Blažene Djevice Marije (1508.) Transit sv. Jeronima (1508.) te Kožičićevoj Knjižici od žitija rim-
} 
Ana Šimić: Mikrostruktura i istraživački izazovi obrade Rječnika crkvenoslavenskoga... FILOLOGIJA 69(2017), 99-128

Jedini glagoljski dokument koji je zajednički korpusu Akademijina Rječnika hrvatskoga ili srpskoga jezika i korpusu Rječnika crkvenoslavenskoga jezika hrvatske redakcije jest Regula sv. Benedikta (14. st.). Ni u drugom desetljeću 21. stoljeća većina glagoljskih dokumenata i rukopisa, pa tako i oni koji čine korpus Rječnika crkvenoslavenskoga jezika hrvatske redakcije, nije ni preslovljeno ni kritički objavljeno, što sam korpus i njegovu obradu u Rječniku čini zasada najsadržajnijim tezurusom srednjovjekovne glagoljske pismenosti. Ukratko, kada je o hrvatskoj leksikografiji riječ, ne postoji djelo koje bi u punom smislu Rječniku moglo biti referentnom točkom.

Ipak, razumljiva je prosudba da to i ne bi trebalo očekivati jer je najrelevantnija referentna točka nekom crkvenoslavenskom rječniku upravo starocrkvenoslavenski rječnik. U skladu je s tim i ono što, između ostaloga, stoji u Uvodu znanstvene urednice Anice Nazor koja navodi da se Rječnik »naslanja na Slovník [jazyka staroslověnského] i nastavlja ga u pravom smislu te riječi« (RCJHR1 2000:III). Nema sumnje da je starocrkvenoslavenski rječnik referentna točka za leksikografski opis bilo kojega crkvenoslavenskoga idioma, ali pritom, kada je o hrvatskom crkvenoslavenskom riječ, valja imati na umu nekoliko činjenica.

Sačuvanih je kanonskih starocrkvenoslavenskih tekstova relativno malo i potječu iz 10. i 11. stoljeća, dok se vremenski okvir znatno obimnijega zadanoga hrvatskoglagoljskog korpusa proteže kroz pet stoljeća: od 12. do 16. stoljeća. Ono što je još važnije jest pitanje nadgradnje obaju književnih jezika, starocrkvenoslavenskoga jednako kao i hrvatskoga crkvenoslavenskoga, odnosno njihova jezična jednako kao i kulturna odnosno društvenopovijesna uvjetovanost. Za razliku od starocrkvenoslavenskoga i ostalih crkvenoslavenskih idioma koji su vezani za istočni, bizantski civilizacijski krug, hrvatski je crkvenoslavenski stasao pod okriljem zapadnoga, tj. rimskoga. Premda je ćirilometodska misija započela u vrijeme jedinstva, godine 1054. dolazi do raskola koji je imao posljedice i na konfesionalnu razdvojenost među redakcijama. $S$ obzirom na jezik to znači da su se prevodili različiti tipovi tekstova, što je nerijetko podrazumijevalo zauzetiji prevodilački zahvat, ponajviše u odnosu na tvorbu riječi, tj. na tvorbu novih leksema i termina. Pripadnost rimokatoličkoj vjeroispovijesti hrvatskim je glagoljašima donijela i latinski jezik kao jezik izvorišnih tekstova, za razliku od grčkoga jezika koji je bio jezikom izvornikom starocrkvenoslavenskih prijevoda, ali i osnovni nositelj istočne, bizantske kulture. Grčki je jezik slavenskim jezicima strukturom sličniji nego latinski. Dokaz je tomu i postojanje tzv. balkanskoga jezičnog saveza kojemu, između osta-

skih arhijereov i cesarov (1531.), v. Rječnik JAZU 1975-1976:550, 553, 554, 555, 559, 561. 
Ana Šimić: Mikrostruktura i istraživački izazovi obrade Rječnika crkvenoslavenskoga... FILOLOGIJA 69(2017), 99-128

lih, pripadaju istočni južnoslavenski idiomi (makedonski, bugarski, srpski torlački govori), ali i grčki jezik. Budući da je starocrkvenoslavenska i crkvenoslavenska pismenost $u$ svojoj biti prijevodna, ne valja zanemariti pretpostavku da različit jezik izvornika potencira različitosti među crkvenoslavenskim idiomima.

U svakom slučaju, rječnici starocrkvenoslavenskoga jezika za obrađivača su Rječnika crkvenoslavenskoga jezika hrvatske redakcije neizbježno i dobrodošlo pomoćno i referentno mjesto, ali to nipošto ne znači da će u njima naći uvijek odgovore na svoja pitanja. Jer razlike između starocrkvenoslavenskoga i njegovih redakcija nisu samo fonološke, kako se često misli, nego se očituju na svim razinama, pa tako i na leksičkoj metarazini. Premda su kvantitativne leksičke usporedbe nešto čemu se paleoslavistika zasada još može samo nadati, na pojedinačnim se manjim uzorcima mogu slikovito pokazati razlike. Primjerice, kada je o podkorpusu niječnih leksema, tj. leksema s predmetcima ne-, bez- i ni- riječ, onda je usporedna raščlamba između starocrkvenoslavenskoga i hrvatskoga crkvenoslavenskoga pokazala da imaju svega 30\% zajedničkih riječi (Kovačević 2016:77). Drugim riječima, udio od $70 \%$ hrvatskih crkvenoslavenskih morfološki niječnih riječi nije potvrđeno u kanonu starocrkvenoslavenskih spisa. Isto tako, ondje gdje postoje isti oblici, ne mora postojati i isto značenje. Primjerice, u oba idioma nedêla znači 'sedmi dan u tjednu' i 'tjedan', ali samo su u hrvatskom crkvenoslavenskom, zbog rimokatoličke tradicije unutar koje se razvijao, potvrđene sintagme s leksemom nedêla, odnosno kolokacije koje su vezane za liturgijsku upotrebu: cvêtna nedêla, gluha nedêla, nedêla puĉeniê, nedêla ot muki, bêla nedêla i dr. (Kovačević 2016:95). Navedeni postoci mijenjat će se od podkorpusa do podkorpusa, od teksta do teksta, a jednom će s završetkom obrade Rječnika komparativnom metodom biti moguće dati cjelovite podatke.

Konačno, o ovom osnovnom izazovu kojem dorasli trebaju biti obrađivači i urednici Rječnika, svjedoči i dugogodišnjih urednica Rječnika, vrsna češka slavistica Zoe Hauptová koja je dvadeset i četiri godine uređivala najobimniji starocrkvenoslavenski rječnik u slavistici, Slovník jazyka staroslověnského, te osamnaest godina Rječnik crkvenoslavenskoga jezika hrvatske redakcije. Ona se, navodi njezina dugogodišnja suradnica Anica Nazor,

»s respektom i poštovanjem odnosila (...) prema hrvatskoj građi, svjesna da se u Staroslavenskom institutu priprema redakcijski rječnik hrvatskoga crkvenoslavenskoga jezika koji se, dakako, razlikuje od rječnika kanonskoga staroslavenskoga jezika. Voljela je isticati: to je rječnik vaše redakcije, pa je važno da u njemu upravo ta redakcija bude vjerno predstavljena, što nije uvijek ni lako ni jednostavno postići.« (Nazor 2012:283). 
Ana Šimić: Mikrostruktura i istraživački izazovi obrade Rječnika crkvenoslavenskoga... FILOLOGIJA 69(2017), 99-128

4.2. Sljedeći izazov s kojim se suočavaju obrađivači i urednici Rječnika odnosi se na jezike predložaka, a to su latinski i starogrčki. Premda latinski i starogrčki više nisu u živoj upotrebi, riječ je o jezicima koji su dobro opisani i koji su studirani stoljećima, što se ne može reći za hrvatski crkvenoslavenski. On je pak, kao što je ranije rečeno, jezik koji je ponajviše nastajao prevođenjem ili prilagođavanjem latinskih i starogrčkih tekstova. Zbog toga se u obradi može nesvjesno upasti u zamku da se, u slučajevima kada nema dovoljno jasnih potvrda neke hrvatske crkvenoslavenske riječi, opisuje jezik predložaka više nego jezik prijevoda, tj. značenje se prijevoda izvodi iz značenja predloška. Valja napomenuti da se pred ovim izazovom nalaze povjesničari jezika, odnosno dijakronijski lingvisti uopće onda kada pred sobom imaju idiom ili tekstove koji su bili u bliskom jezičnom kontaktu s nekim drugim jezikom, pogotovo ako je taj drugi jezik bio prestižniji i rasprostranjeniji. Primjerice, starocrkvenoslavenski i crkvenoslavenski niječni imperativ s pomoćnim glagolom moĉi i infinitivom glagola nositelja semantičkoga značenja (npr. ne mozêmъ ubo posramiti) pripisivao se utjecaju sličnih starogrčkih i latinskih konstrukcija, što se ipak pokazalo da nije ispravno tumačenje (vidi više Reinhart 2016:406-407).

Kako se u povijesnoj leksikografiji nositi s tim izazovom, slikovito će pokazati primjer obrade leksema žusta (RCJHR2 2016:583). ${ }^{18}$ Veličina je rječničkoga članka posvećenoga toj imenici 326 znakova s razmacima, što predstavlja svega $18 \%$ autorske kartice teksta (vidi Prilog 1.). Leksem je žusta potvrđen u samo jednom retku starozavjetne Pjesme nad pjesmama $(7,2)$. No put od ekscerpcije primjera iz izvora do konačnoga objavljivanja rječničkoga članka nije bio ni brz ni jednostavan.

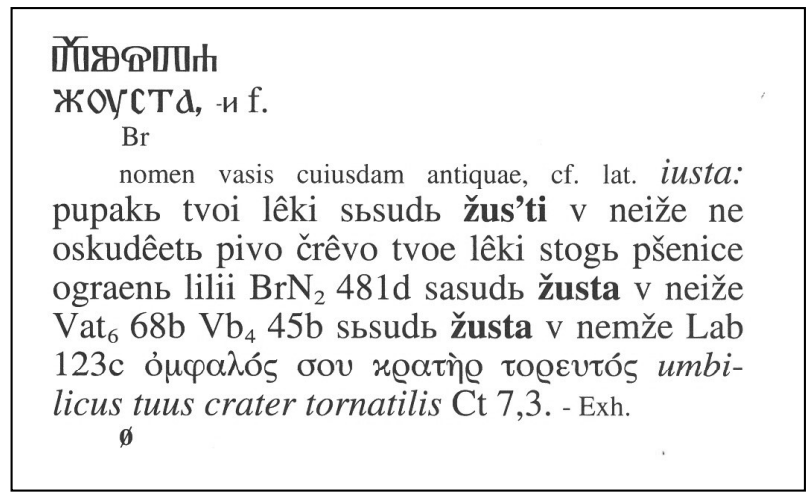

Prilog 1.

${ }^{18}$ Zahvaljujem kolegi Jozi Veli što mi je skrenuo pozornost na slučaj natuknice žusta. 
Ana Šimić: Mikrostruktura i istraživački izazovi obrade Rječnika crkvenoslavenskoga... FILOLOGIJA 69(2017), 99-128

Obrađivač (Jozo Vela) koji nije bio ni rođen kada je ekscerpcija glagoljskih izvora za Rječnik završena, mogao je brzo postati svjestan da pred sobom ima potencijalno tvrd orah. $\mathrm{O}$ tome govori znak $\varnothing$ na kraju rječničkoga članka koji daje do znanja da ovaj leksem nije potvrđen ni u Slovníku jazyka staroslověnského ni u Miklošičevu Lexicon palaeoslovenico-graece-latinum ni u Akademijinu Rječniku hrvatskoga ili srpskoga jezika. Drugim riječima, sve, odnosno jedino što je obrađivač imao pred sobom bila je jedna jedina potvrda zadane riječi $u$ jednom jedinom glagoljskom retku koji prenosi nekoliko brevijara i gramatičku identifikaciju koju su na kartotečnom korpusu utvrdili njegovi iskusni prethodnici, tj. ekscerptori korpusa (vidi Prilog 2. i Prilog 3.). ${ }^{19}$ Oni su riječ gramatički identificirali kao pridjev, nadopisavši latinsku i grčku odgovarajuću riječ, a to su pridjevi tornatilis 'za-

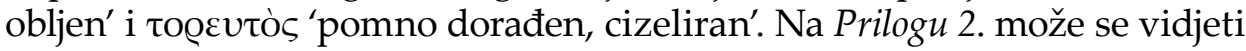
i da je dopisana bilješka o članku Josipa Hamma iz 1957. godine.

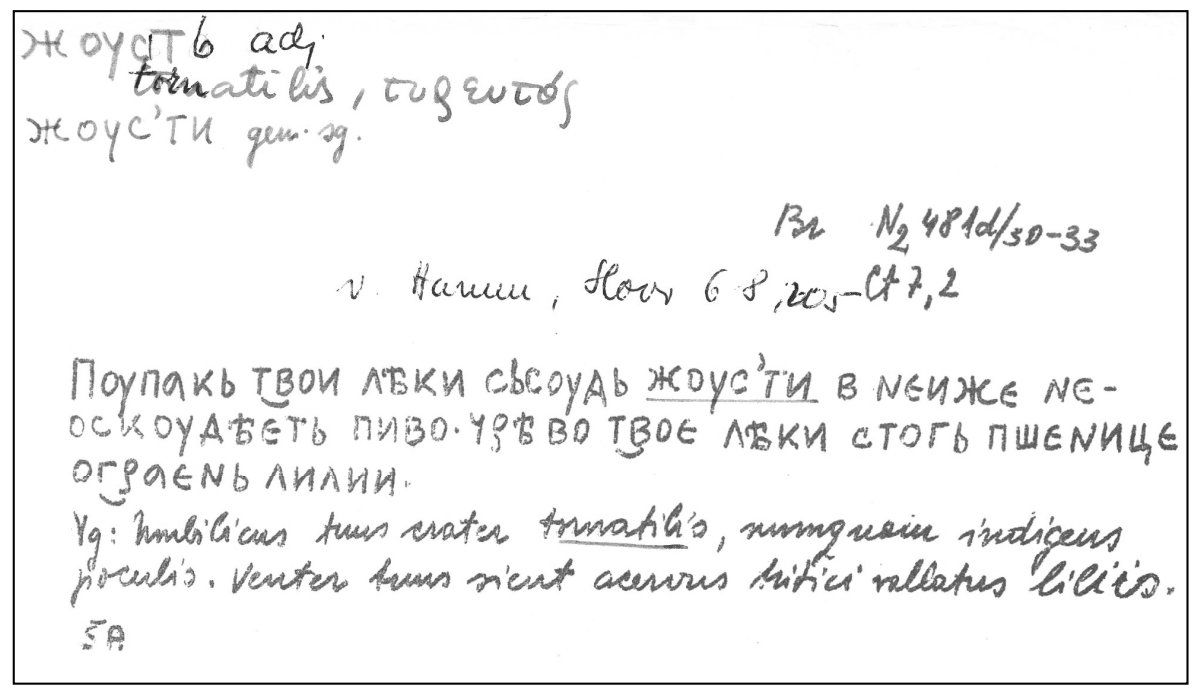

Prilog 2.

${ }^{19}$ Više o kartotečnom korpusu Rječnika crkvenoslavenskoga jezika hrvatske redakcije vidi u Vukoja 2012. i 2014. 
Ana Šimić: Mikrostruktura i istraživački izazovi obrade Rječnika crkvenoslavenskoga... FILOLOGIJA 69(2017), 99-128

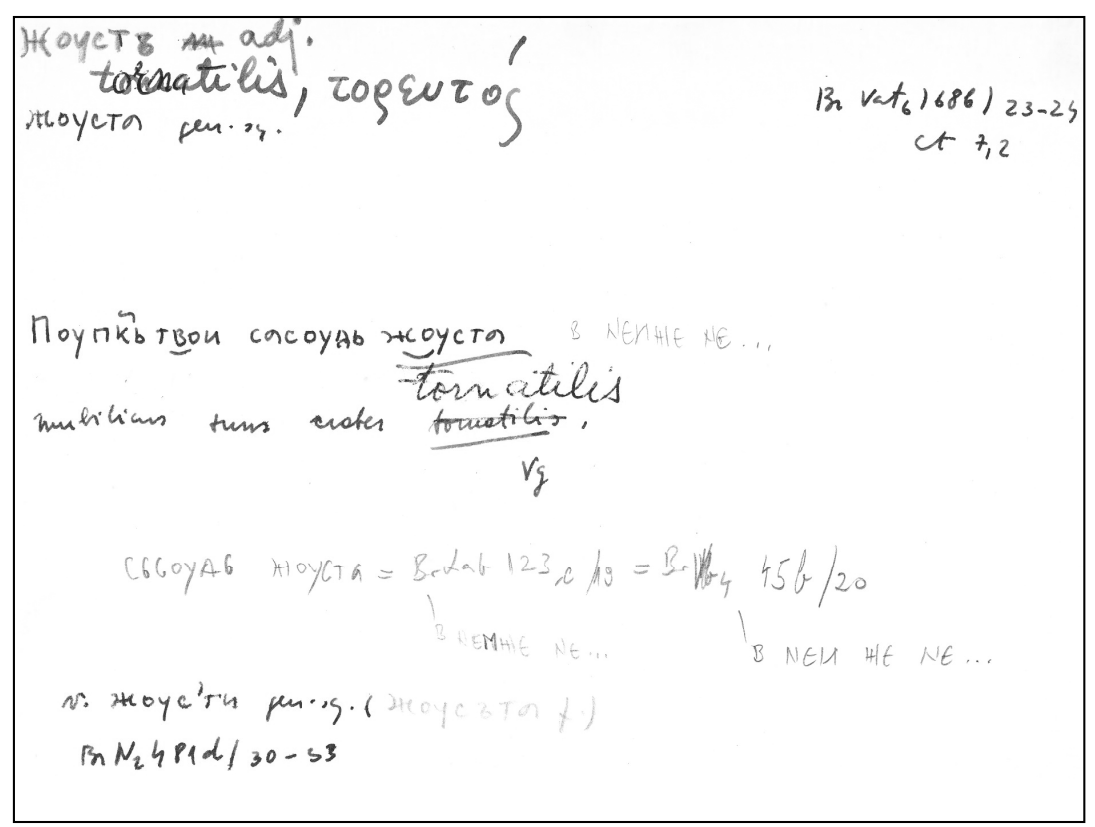

Prilog 3.

U članku iz 1957. pod naslovom Starohrvatski prijevod Pjesme nad pjesmama Hamm je za neka mjesta $\mathrm{u}$ hrvatskom crkvenoslavenskom prijevodu Pjesme nad pjesmama (koji on naziva terminom starohrvatski) utvrdio da su »krivim prepisivanjem i posljedicama kriva prepisivanja sasvim iskrivljena (Hamm 1957:204). Jedno od takvih mjesta je, smatra Hamm, upravo ovaj kobni redak iz sedme glave, potvrđen u IV. vrbničkom brevijaru:

(1) Pupık' tvoi sbsudo žusta · v neiže ne oskudêet' pivo - $\mathrm{BrVb}_{4}(\mathrm{Pj} 7,2)$

Taj isti redak na suvremenom hrvatskom glasi Pupak ti je kao okrugla čaša koja nikad nije bez pića.

Hamma je u ovom primjeru zasmetao oblik odnosne zamjenice neiže koji je ženskoga roda, a očekivan bi, smatra, bio oblik muškoga roda jer se zamjenica odnosi na sbsudb koji je muškoga roda. Zbog toga pretpostavlja da je ovaj redak trebalo glasiti ?sssudb žusto ili žustro vo nemže. Može se primijetiti da je Hamm, jednako kao oni koji su ekscerpirali korpus, smatrao da je žusta iskrivljeni oblik pridjeva, što je u skladu s latinskom, crater

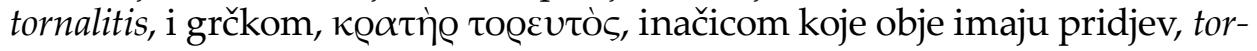

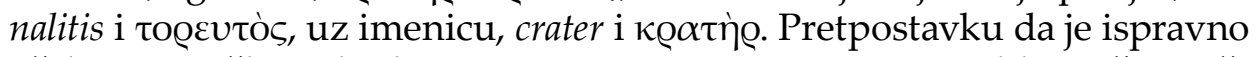
očekivati muški rod odnosne zamjenicu Hammu je potvrdila inačica raščlanjenoga retka iz I. ljubljanskoga brevijara u kojem doista stoji $v^{\prime}$ nemže, što 
Ana Šimić: Mikrostruktura i istraživački izazovi obrade Rječnika crkvenoslavenskoga... FILOLOGIJA 69(2017), 99-128

je muški rod:

(2) pupakb tvoi şsudb žusta $\cdot v^{\prime}$ nemže ne os'kudêets pivo - BrLab(Pj 7,2)

No s druge strane, sve se opet komplicira inačicom iz II. novljanskoga brevijara u kojem nema oblika žusta, nego žusti:

(3) pupaks tvoi lêki sbsuds žus'ti v neiže ne oskudêets pivo- $\mathrm{BrN}_{2}(\mathrm{Pj} 7,2)$

Konačno, Hamm navodi i mogućnost da je pisarima mjesto bilo nejasno, ako su poimali žusto kao imenicu. Završna identifikacija riječi u Rječniku crkvenoslavenskoga jezika hrvatske redakcije nije identificirala žustu kao pokvareno ili nejasno mjesto, pa ni kao pridjev, nego upravo kao imenicu ženskoga roda.

Da bi se do toga došlo valjalo je uhvatiti se u koštac s uvijek prisutnim izazovom, odnosno zamkom da se predložak, bilo latinski bilo grčki, smatra mjerodavnim za određivanjem gramatičke i semantičke identifikacije hrvatske crkvenoslavenske riječi. Predlošci uvelike olakšavaju obradu, ali bi se valjalo nastojati opisivati jezik iz njega samoga, a ne iz njegova kontakta s drugim jezicima, u ovom slučaju sa starogrčkim ili latinskim. Ako je neka riječ u predlošku pridjev, to ne znači da se isto mora očekivati i u jeziku prijevoda. Osim toga, valja se oduprijeti i sklonosti da se na prvi, pa i drugi i treći pogled suvremenom obrađivaču nejasna mjesta olako tretiraju kao pogreške glagoljskoga pisara ili rezultati pisareva nerazumijevanja teksta. Potrebno je dobrano se potruditi interpretirati manje jasne riječi, sintagme i rečenice prije nego ih se konačno proglasi greškama u prijevodu ili prijepisu.

Premda je, u ovom konkretnom slučaju, obrađivač dobio u nasljedstvo identifikaciju žuste kao pridjeva, nije propustio priliku da takvu identifikaciju preispita. To ga je i dovelo do rezultata da je žusta imenica i uz zeleno svjetlo iskusnijih urednika takva je njegova obrada postala službena. Kako je obrađivač došao do toga? Sama istraživačka intuicija nije dovoljna, ona samo daje početni impuls.

Budući da je identifikacija žuste kao pridjeva povlačila sa sobom mnogo ograda, druga je mogućnost bila pretpostaviti neku drugu identifikaciju koja neće imati uporište u predlošcima. Po svoj prirodi stvari nametala se mogućnost ne samo da su pisari greškom poimali žustu kao imenicu nego da ona doista jest imenica. Prema tom polazištu, imenska skupina sbsudo žusta i sbsusdo žusti ne sastoji se od imenice i pridjeva, nego od imenice i druge imenice.

Da je obrađivač bio na dobrom tragu, pokazuje činjenica da je iz takve 
Ana Šimić: Mikrostruktura i istraživački izazovi obrade Rječnika crkvenoslavenskoga... FILOLOGIJA 69(2017), 99-128

perspektive moguće pojasniti zašto je odnosna zamjenica jednom u ženskom rodu ( $v$ neiže), a u drugom rukopisu u muškom rodu ( $v^{\prime}$ nemže). Budući da se imenska skupina sastoji od dvije imenice, kontrolorom sročnosti mogu biti obje sastavnice imenske skupine. U primjerima (1) i (3) kontrolor je sročnosti imenica ženskoga roda žusta, pa se odnosna zamjenica slaže s njom u rodu. U primjeru pak (2) kontrolorom je imenica muškoga roda $s b s u d b$, pa se odnosna zamjenica slaže s njom u rodu. Koja će sastavnica imenske skupine biti kontrolorom sročnosti ovisi i o tome koju je od njih pisar poimao semantički relevantnijom.

$\mathrm{Na}$ to se nadovezuje pitanje o vrsti pretpostavljene imenske skupine sbsusdo žusta i sbsudo žust'i Kada je o gramatici riječ, može se uočiti da je prva imenska skupina sročna, odnosno obje su sastavnice $u$ istom broju i padežu: nominativu jednine. Druga je imenska skupina upravljana, tj. prva sastavnica sssudo upravlja drugom sastavnicom koja nije u nominativu, nego u genitivu: žusti je očekivani genitiv jednine imenica ženskoga roda glavne a/ja promjene. Dvije imenice i mogućnost da ne budu u istom padežu upućuju na pretpostavku da je jedna od njih apozicija drugoj. U literaturi se nalazi potvrda takve pretpostavke. Razlažući sintaksu novozavjetnoga grčkoga jezika, Daniel B. Wallace navodi kako valja razlikovati jednostavne apozicije od onih složenih. Jednostavne su one u kojima su obje imenice $u$ istom padežu, a složene su one $u$ kojima je druga imenica u genitivu. Takav genitiv naziva genitivom apozicije dodajući mu još termin epegzegetički genitiv odnosno genitiv definicije. ${ }^{20}$

U složenim apozicijama prva imenica označava kakvu širu kategoriju, dok ona druga u genitivu predstavlja konkretan ili specifičan primjer(ak) te kategorije. Drugim riječima, u primjeru ovdje raščlanjenom, prva je sastavnica $s b s u d b$ hiperonim, a druga je sastavnica žusti njezin hiponim. I u suvremenom je hrvatskom jeziku moguće naći supostojanje sročne i upravljane imenske skupine s apozicijom, odnosno jednostavnih i složenih apozicija, npr. drvo javor, u kojem su oba člana imenske skupine, hiperonim i hiponim, u nominativu. No može se reći i drvo javora, pri čemu je druga sastavnica u genitivu (apozicije).

Budući da su uspostavljeni gramatički odnosi sugerirali da je sbsudb apozicija i hiperonim imenice žusta, a ona njegov hiponim, odnosno da je značenjski uža i da specificira značenje sssuda, neizbježna je bila i pretpostavka da žusta označava nekakvu vrstu, odnosno tip ovalne posude koji je bio poznat u srednjovjekovlju. Budući da mu je nemoguće naći sinonime $u$ suvremenom hrvatskom i engleskom jeziku, $u$ rječničkom je član-

${ }^{20}$ Vidi Wallace 1996:94-95; usp. Turkalj 2012:153-154. 
Ana Šimić: Mikrostruktura i istraživački izazovi obrade Rječnika crkvenoslavenskoga... FILOLOGIJA 69(2017), 99-128

ku dan opis značenja na latinskom nomen vasis cuiusdam antique što znači ‘ naziv neke starinske vaze'. No ni ta odrednica nije olako napisana. Premda nije imao traga ove riječi ni u kojem starocrkvenoslavenskom ili hrvatskom rječniku, obrađivač je pokušao naći neku sličnu riječ izvan slavenskoga svijeta polazeći od toga da je žusta vjerojatno čakavizam u zadanom hrvatskom crkvenoslavenskom korpusu, ali je unutar čakavskoga idioma srednjovjekovnoga razdoblja vjerojatno bila posuđenica iz nekoga drugoga jezika. Pretpostavivši da je riječ o latinskom jeziku, službenom jeziku srednjovjekovne Europe, u Marevićevu je rječniku pronašao imenicu iusta sa značenjem 'mjera za tekućine i žitke, suhe tvari: polovina pinte' (Marević 2000:1672), što mu je potvrdilo da je na dobrom tragu. Konačno, u uglednom rječniku srednjovjekovnoga latiniteta Mediae latinitatis lexicon minus (Niermeyer 1976:569) traga za istim oblikom i nalazi ga u značenju mjere pića jednako kao i posude pića, što je bila konačna potvrda da žustu gramatički identificira kao imenicu ženskoga roda, a semantički kao vrstu srednjovjekovne ovalne posude.

Preostaje se samo još nadati da će se buduće filološke i leksikografske obrade povijesnih hrvatskih idioma, pa tako i čakavskoga, naići u svojim korpusima na ovu riječ te potvrditi njezinu obradu objavljenu u Rječniku crkvenoslavenskoga jezika hrvatske redakcije.

4.3. Jedan od stalnih izazova dijakronijske lingvistike uopće, pa tako i povijesne leksikografije jest nositi se s činjenicom da dobro poznavanje sinkronije i upućenost u sinkroniju nekoga idioma nerijetko ometa objektivno otkrivanje i tumačenje njegove dijakronijske dimenizije. Ovom su izazovu posebno podložni izvorni govornici nekoga jezika kada proučavaju povijest jezičnih jedinica i jezičnih struktura ili njihovo stanje u određenom povijesnom odsječku u trenutku kada su iste te jedinice i/ili strukture prisutne i u suvremenom jeziku.

Takvo je, primjerice, niječno slaganje. Riječ je o tipološki važnoj sintaktičkoj pojavi kada se jedinstveno niječno značenje komunicira pomoću dvije ili više niječnih riječi. Prepoznatljiv je oblik niječnoga slaganje ono između niječnih zamjenica, priloga i pridjeva sa zanijekanim predikatom, npr. Ništa ne razumijem. U suvremenim se slavenskim jezicima, pa tako i u hrvatskom, niječno slaganje provodi uvijek, neovisno o redu riječi. Kada su pojedini povjesničari jezika u hrvatskim povijesnim idioma uočili primjere u kojima se niječno slaganje ne provodi, takvu su nepodudarnost sa suvremenim hrvatskim olako protumačili kao utjecaj latinskoga jezika ili romanskih jezika (vidi više u Kovačević 2013:502-505; Kovačević 2016:242243). No objašnjenje se krije u evolutivnoj naravi jezičnih pojava i u činjenici da prvi posvjedočeni slavenski književni jezik, starocrkvenoslavenski, 
Ana Šimić: Mikrostruktura i istraživački izazovi obrade Rječnika crkvenoslavenskoga... FILOLOGIJA 69(2017), 99-128

koji je nastajao prevođenjem sa starogrčkoga, također ne provodi uvijek niječno slaganje. Riječ je o tzv. djelomičnom niječnom slaganju, ovisnom o redu riječi, koje je u povijesti hrvatskoga jezika bilo duže na snazi od potpunoga niječnoga slaganja.

Da bi se takvi previdi izbjegli, istraživač valja biti svjestan vlastite pristranosti te se truditi ne donositi brze i neprovjerene zaključke. Osim toga, valja širiti i vlastita lingvistička obzorja neprestanim upoznavanjem s postignućima tipološke i komparativne lingvistike. Kao i u svim dosada navedenim izazovima i ovdje je jedna od dobrodošlih okolnosti timski rad, odnosno plodna suradnja istraživača, urednika, recenzenata i dr.

Primjeri koji se ovdje mogu navesti jesu riječi iz zadanoga hrvatskoga crkvenoslavenskoga korpusa koje su, s obzirom na neke slavenske idiome koji su obrađivaču poznatiji i jasniji od zadanoga, prepoznatljivoga oblika i naizgled prozirnoga značenja. Može se reći da je riječ o svojevrsnim lažnim dijakronijskim prijateljima, primjerice žalovanie (RCJHR2 2016:532). U Akademijinu rječniku ovoj su prepoznatljivoj riječi pridodana značenja 'žaljenje, tugovanje, tužba', a isto to značenje ima i danas. No takvo stanje obrađivača ne smije zavarati. Jedan jedini primjer u korpusu Rječnika crkvenoslavenskoga jezika hrvatske redakcije označava posve drukčiju prirodu emocionalnoga angažmana od žaljenja i tugovanja: označava 'žudnju'. Da o žalovanju nije riječ, pokazuje i latinska sintagma compassiva dulcedine koja se pak može približno prevesti kao 'suosjećajna slatkoća'. No dublje iščitavanje teksta pokazuje da ovaj latinski »pjesnički izraz« nije odgovarajući prijevod i zato obrađivač mora naći prikladnu latinsku riječ za hrvatsku crkvenoslavensku 'žudnju', a to je desiderium koji je napisan u kurzivu. Kao što je ranije rečeno (vidi 2.), kada se latinski sinonim hrvatskoga crkvenoslavenskoga leksema bilježi kurzivom, to znači da nije potvrđen u predlošku, nego ga je obrađivač preveo, tj. našao je primjerenu latinsku inačicu hrvatskom crkvenoslavenskom leksemu. Na primjeru žalovanie vidi se kako predlošci jesu dobrodošli u određivanju značenja riječi. Da, primjerice, za ovaj tekst nije utvrđen predložak i da je obrađivač bio pod snažnim utjecajem ne samo sinkronijskoga značenja leksema žalovanje koje odgovara njegovu poznatom povijesnom značenju iz Akademijina rječnika, znatno bi lakše u opisu ove natuknice, primjerice, dometnuo opise translatio minus apta ili translatio erronea. No istraživačka svjesnost o mogućim zamkama u određivanju značenja olakšava ispravnu obradu koja će obogatiti semantičke spoznaje o ovoj prepoznatliivoj riječi.

Još jedan primjer prepoznatljive riječi jest dlogota. Prilog 4. pokazuje kako izgleda njezina obrada u Rječniku crkvenoslavenskoga jezika hrvatske redakcije (RCJHR2 2016:299-300). Ova je riječ potvrđena i u starocrkvenosla- 
Ana Šimić: Mikrostruktura i istraživački izazovi obrade Rječnika crkvenoslavenskoga... FILOLOGIJA 69(2017), 99-128

venskom jeziku, pa je, dakako, obrađena i u najvećem i najpoznatijem staroslavenskom rječniku Slovníku jazyka staroslověnského (Slovník 1968:486), što pokazuje Prilog 5.

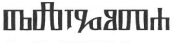

АльГОТА, -и f.

M; Br; Ps; Rit; CPar Pet Tk Grš

duljina; lenght; - $-\mu \tilde{\eta}$ ros; longitudo, prolixitas, spatium: da vzmožete postignuti sь vsêmi s(ve)timi čto est' dlıgota širota visota i glubina ... ljubvi h(rbsto)vi MVat ${ }_{4} 146 \mathrm{~d} \mu \tilde{\eta}-$ xos longitudo E 3,18; trista lakat' budet' $\mathrm{v}$ dlsgotu kovčeg' $\mathrm{MVat}_{4} 100 \mathrm{~b}$ Nov $100 \mathrm{c}$ Lab 90d BrVO 134a Vb 1 91b Pm 67b Vat, 66d N

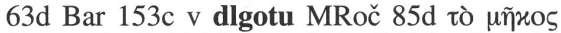
longitudo $\mathrm{Gn} 6,15$; i gradı na četiri ugli stoit' dlıgota ego elikože i širota BrVO 281a dlgota $\mathrm{N}_{2} 142 \mathrm{c}$ êko $\mathrm{v}$ dlgotu Vat ${ }_{5}$ 135a tò uñros longitudo Ap 21,16; dlgotoju nedugi

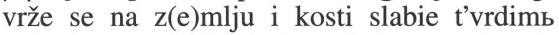
vrženiemb razbi BrVat $_{6} 191 \mathrm{~b}$ prolixitate languoris; vrêmen'ni životb vêčnomu životu pripodoblenь semrtb e(stb) veĉe rekoma neže životb to bo vsedan'ne poman'kanie skrušeniemb čto estı tıkmo nêkaê dl(b)gota semrti $\mathrm{BrN}_{2} 332 \mathrm{~b}$ Ac 46c Vat ${ }_{6} 43 \mathrm{~b} \mathrm{Vat}{ }_{19} 232 \mathrm{c}$ Bar 456b prolixitas mortis; po kratkim' že $\operatorname{vr}(\hat{\mathrm{e}})$ $\mathrm{m}(\mathrm{e}) \mathrm{n}(\mathrm{e}) \mathrm{mb}$ zêlo dlgoti roka k’ v(ê)čn(a)go božstviê radostemb pošlju vi BrVat $_{6}{ }_{109} \mathrm{c}$ temporis spatii \ dl'gine $\mathrm{N}_{2} 421 \mathrm{a}$;

Альгота Аьми, житић duljina života;

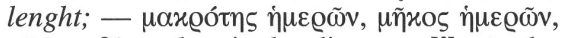

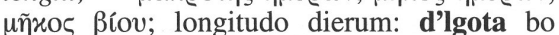
d(b)ni v' desnici ee MNov 236 $\mathrm{BrN}_{2}$ 191d $\mathrm{Vb}_{1} 226 \mathrm{a} \mathrm{Vat}_{5}$ 174a dlbgota ... omm. $\mathrm{MVat}_{4}$ 234d d[d]lıgota bo žitiê BrVO 352d $\mu \tilde{\eta}$ นos

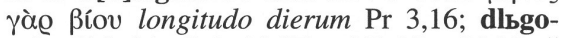
toju d(b)ni ispl'nju i MVat ${ }_{4} 29$ b Nov 30d Roč 23d BrAc 22a PsPar 54v Fr 76b Lob 61v

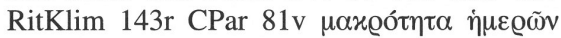
longitudine dierum Ps 90,16; domu tvoemu podobaetb $\mathrm{s}(\mathrm{ve})$ tina $\mathrm{g}(\mathrm{ospod}) \mathrm{i} \mathrm{v}$ dl'gotu d(b)ni $\mathrm{BrN}_{2} 354 \mathrm{a}, 352 \mathrm{a}$ PsLob 62r BrVat ${ }_{6} 62 \mathrm{a}$

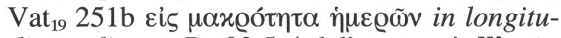
dinem dierum Ps 92,5; i dal' emu esi dl'gotu

\section{Prilog 4.}

Činjenica da je hrvatska crkvenoslavenska obrada opsežnija od starocrkvenoslavenske, preslikava odnos veličine korpusa: kao drevniji idiom starocrkvnoslavenski jezik ima ograničeniji korpus od hrvatskoga crkvenoslavenskoga. Osnovno im je značenje zajedničko, pa čak i učestala sveza dlogota doni, koja je u hrvatskoglagoljskom korpusu dolazi i u inačici dlogota žitiê. Drugo pak značenje 'velikodušnost, strpljivost' nije potvrđeno ni u starocrkvenoslavenskom ni u kasnijim hrvatskim idiomima ni u suvreme- d(b)ni v' v(ê)kb i vb v(ê) kb v(ê)ka MVat 208c Nov 217d $\mathrm{BrN}_{2} 333 \mathrm{a} \mathrm{Vat}_{6} 44 \mathrm{~b} \mathrm{Ac}$ 4d,47c Vat ${ }_{19}$ 232d Bar 473c PsPar 16r Fr 20b Lob 12r $\mu \alpha x \varrho o ́ \tau \eta \tau \alpha ~ \dot{\eta} \mu \varepsilon \varrho \tilde{\omega} v$ longitudinem dierum Ps 20,5 \ dl'gost' d(b)ni CPar 21v; sim. priložitb ti se BrVO $352 \mathrm{c}$ dlgota d(b)ni $\mathrm{N}_{2}$

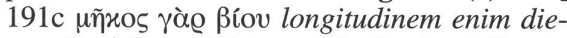
misli i dlgotu žitiê CTk 102r;

velikodušnost, strpljivost; magnanimity, patience; - $-\mu \alpha \operatorname{xo\theta vuí\alpha ;~longanimitas:~plod~}$ že d(u)hovni est' ljubv' radost' mir' trıpênie dlsgota dobrota MVat ${ }_{4}$ 145a dlgota Lab 121d Nov 142b $\mu \alpha x \varrho o \theta v \mu i \alpha$ longanimitas G 5,22; sas'tavlajuĉe se êko b(o)ži slugi v' pos'tê v' čis'totê v' razumê v' dlgotê $\mathrm{BrN}_{2} 73 \mathrm{~d} \mathrm{MNov}$ $31 \mathrm{a} \varepsilon v \mu \alpha x \rho o \theta v \mu i \alpha$ in longanimitate $2 \mathrm{C} 6,6 \mathrm{I}$ v tr'pêni Vat ${ }_{4} 29 \mathrm{c}$; ti že poslêdova mi učeniju moemu žitiju voli vêrê krotkosti dlıgotoju ljubvi tr'pêniju $\mathrm{MVat}_{4}$ 235b dlgotoju Lab

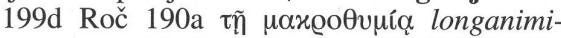
tatem 2T 3,10; da li u bogatastvê bl(a)g(o)dêti ego trpêni i dlgoti ne rodiši hulei BrVat $_{5} 51 \mathrm{c}$

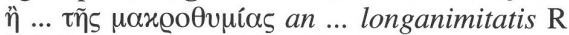
2,4 \ АльготрьПБниє, трьпъмиє, оуАрьжание. Cf. Anb $\mathrm{SOCT \textrm {T }}$
SM A(dugota) $\mathrm{BrN}_{2} 408 \mathrm{a}$; dl'gota bo žitiê i lêta žizni i miru rum $\operatorname{Pr} 3,2$; podaĵ emu celenie tela i čistotu 
Ana Šimić: Mikrostruktura i istraživački izazovi obrade Rječnika crkvenoslavenskoga... FILOLOGIJA 69(2017), 99-128

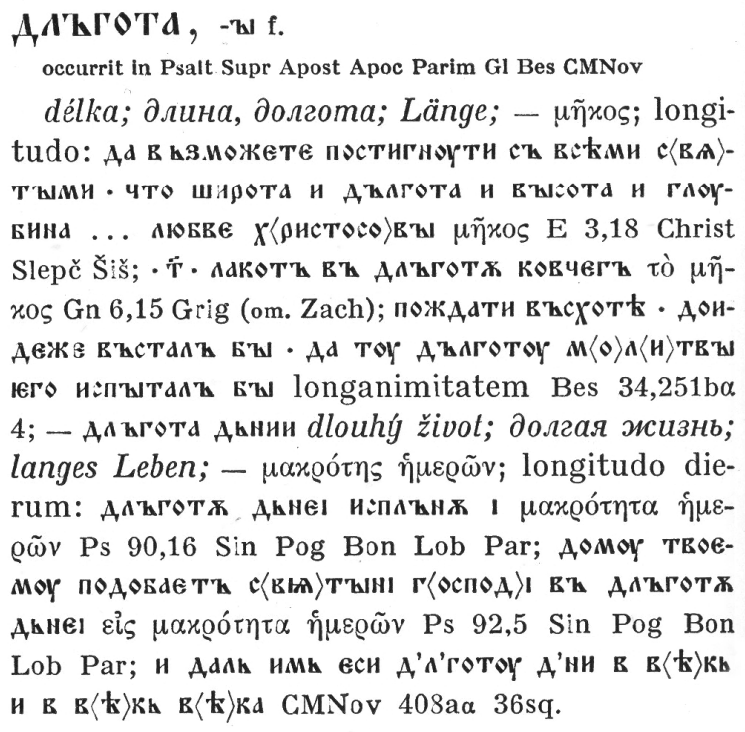

Prilog 5 .

nom hrvatskom jeziku. Korisnik će zahvaljujući informativnosti rječničkoga članka uočiti da su zabilježeni primjeri svojina novozavjetnih Pavlovih poslanica. Zašto i kako je došao prijenos navedenoga značenja na imenicu koja je prvotno značila 'duljina' zanimljiva je tema koja će u budućnosti možda naići na semantičara spremnoga da se s njome uhvati u koštac.

\section{Zaključak}

Rječnik crkvenoslavenskoga jezika hrvatske redakcije jedan je od temeljnih dugoročnih projekata Staroslavenskoga instituta i jedan od važnijih dugova paleokroatistike ukupnoj hrvatskoj i slavističkoj filologiji. Sadržajnost rječničkoga članka, odnosno njegova mikrostruktura koja pregnantno i detaljno donosi ortografske i grafijske, gramatičke, semantičke, stilističke, distribucijske, ilustrativne, međujezične i uporabne podatke, omogućuje iščitavanje, razumijevanje i tumačenje hrvatskoglagoljskih tekstova crkvenoslavenske provenijencije čiji komunicirani sadržaji nisu samo predmetom filologije. Osim toga, zahvaljujući svojoj sadržajnosti, Rječnik i sam postaje izvorom i korpusom na kojem se mogu temeljiti različita lingvistička i filološka, samostalna ili komparativna istraživanja hrvatske crkvenoslavenske pismenosti.

Istraživački izazovi o kojima je ovdje bilo riječi na određeni su način zajednički svim povijesnim lingvistima, a u ovom konkretnom slučaju proizlaze iz naravi hrvatskoga crkvenoslavenskoga jezika. Riječ je o povije- 
Ana Šimić: Mikrostruktura i istraživački izazovi obrade Rječnika crkvenoslavenskoga...

FILOLOGIJA 69(2017), 99-128

snom i književnom idiomu koji nikome nije bio materinji jezik i čiji su tekstovi bili prijevodi latinskih i starogrčkih predložaka. Razumljivo je da višestoljetna distanca i činjenica da su obrađivaču nerijetko predlošci jasniji od prijevoda dovode do opasnosti da se semantička identifikacija hrvatske crkvenoslavenske riječi izvodi iz latinskoga, starogrčkoga, starocrkvenoslavenskoga te iz mlađih hrvatskih idioma ili samoga suvremenoga hrvatskog jezika. Neprestano osvješćivanje takvih zamki, nadopunjavanje i produbljivanje vlastitih lingvističkih znanja i kompetencija te timski rad načini su koji olakšavaju prevladavanje tih izazova.

\section{Literatura}

Bláhova, Emilia. 1997. Rječnik crkvenoslavenskoga jezika hrvatske redkacije. Glavni urednici Biserka Grabar, F. V. Mareš. Staroslavenski zavod, Zagreb. 1. Uvod, s. I-XLVIII, 1991; 2. s. 1-64 a-antiohiskb 1992; 3. s. 65-128 antiohiskb - bezlêtnoe 1993; 4. s. 129-192 bezmlbvie - bliz'nv 1994; 5. s. bliznocb-bês 1995. Ročnik 66, 221-223.

Burkhanov, Igor. 2003. Pragmatic specifications: Usage indications, labels, examples; dictionaries of style, dictionaries of collocations. A Practical Guide to Lexicography. Edited by Piet van Sterkenburg. 2003. Amsterdam / Philadelphia. John Benjamins Publishing Company, 102-113.

Geeraerts, Dirk. 2003. Meaning and definition. A Practical Guide to Lexicography. Edited by Piet van Sterkenburg. 2003. Amsterdam / Philadelphia. John Benjamins Publishing Company, 83-93.

Грковић-Мејџор, Јасмина. 2007. Rječnik crkvenoslavenskoga jezika hrvatske redakcije, I. svezak (a-vrêdb), Staroslavenski institut, Zagreb, 2000, 576. str. Прилози за кюижевност, језик, историју і и фолклор, кюь. LXXII, c6.1-4, 185-187.

Hamm, Josip. 1957. Starohrvatski prijevod »Pjesme nad pjesmama«. Slovo 6/7/8, 195-230.

Harambašić, Ermina. 2001. Uzorni ogled za povijesni rječnik. Rasprave Instituta za hrvatski jezik i jezikoslovlje 27, 373-377.

Hartmann, R. R. K; James, Gregory. 2002. Dictionary of Lexicography. London, New York: Routledge. XV, 176 str.

Holzer, Georg. 1996. Rječnik crkvenoslavenskoga jezika hrvatske redakcije. Lexicon linguae slavonicae redactionis croaticae, Zagreb (Staroslavenski zavod Hrvatskoga filološkog instituta) 1991-. Wiener Slavistisches Jahrbuch, Band 42, 318.

Marević, Jozo. 2000. Latinsko-hrvatski enciklopedijski rječnik. I. svezak: A-L. Velika Gorica: Marka; Zagreb: Matica hrvatska. 3648 str.

Nazor, Anica. 1963. Jezični kriteriji pri određivanju donje granice crkveno- 
Ana Šimić: Mikrostruktura i istraživački izazovi obrade Rječnika crkvenoslavenskoga... FILOLOGIJA 69(2017), 99-128

slavenskoga jezika u hrvatskoglagoljskim tekstovima. Slovo 13, 68-86.

Nazor, Anica. 1997. Napomene o izvorima Rječnika crkvenoslavenskoga jezika hrvatske redakcije. М. Миовски, Д. Пандев, Е. Црвенковска (ред.). Зборник во чест на Радмила Угринова-Скаловска по повод седумдесетгодиннината. Скопје: Универзитет »Св. Кирил и Методиј «, Филолошки факултет, 195-200.

Nazor, Anica. 2012. In memoriam: Zoe Hauptová (Brno, 9. II. 1929. Prag, 23. I. 2012.). Slovo 62, 278-283.

Niermeyer, Jan Frederik. 1976. Mediae Latinitatis lexicon minus: lexique latin médiéval-français/anglais. A medieval Latin-French/English dictionary. Leiden: E. J. Brill. xviii, 1138 str.

RCHJR1 2000. Rječnik crkvenoslavenskoga jezika hrvatske redakcije. I. svezak: $a^{1}$ - vrêd b. Zagreb: Staroslavenski institut. xlviii, 576 str.

RCHJR2 2016. Rječnik crkvenoslavenskoga jezika hrvatske redakcije. I. svezak: vrêd ons - zapovêdnica. Zagreb: Staroslavenski institut. 640 str.

Rehder, Peter. 2004. Rječnik crkvenoslavenskoga jezika hrvatske redakcije. Lexicon linguae slavonicae redactionis croaticae. I. svezak: a-vrêdb. Zagreb: Staroslavenski institut 2000 (i. e. 2002). VIII, XLVIII, 576 S. Die Welt der Slaven, Jahrgang XLIX, 1, 199-200.

Reinhart, Johannes.2016. The Extent of the Works of St. Methodius: Syntactic Observations. The Bible in Slavic Tradition. Alexander Kulik, Catherine Mary MacRobert, Svetlina Nikolova, Moshe Taube and Cynthia M. Vakareliyska (eds.). Leiden: Brill, 393-412.

Rječnik JAZU 1975-1976. Rječnik hrvatskoga ili srpskoga jezika. Dio XXIII (2. zlotvor - žuknuti, Popis izvora, Dodatak). Zagreb: JAZU. 564 str. 144 str. (Dodatak).

Slovník 1968. Slovník jazyka staroslověnského. Lexicon linguae paleoslovenicae. I/2. Praha: Nakl. Ceskoslovenské akademie věd. 385-853 str.

Simeon, Rikard. 1969. Enciklopedijski rječnik lingvističkih naziva II: P - Ž. Zagreb: Matica hrvatska.xiii,926. str.

Pit Swanepoel. Dictionary typologies: A pragmatic approach. A Practical Guide to Lexicography. Edited by Piet van Sterkenburg. 2003. Amsterdam / Philadelphia. John Benjamins Publishing Company, 44-69.

Vukoja, Vida. 2012. O korpusu Rječnika crkvenoslavenskoga jezika hrvatske redakcije i njegovu odnosu prema korpusima hrvatskoga jezika. Filologija 59, 207-229.

Vukoja, Vida. 2014. The Corpus of the Croatian Church Slavonic Texts and the Current State Of Affairs Concerning the Dictionary of the Croatian Redaction of Church Slavonic Compiling. A. Abel, C. Vettori, N. Ralli (eds.). Proceedings of the XVI EURALEX International Congress: The User in Focus.15-19 July 2014, Bolzano / Bozen. Bolzano / Bozen: EURAC 
Ana Šimić: Mikrostruktura i istraživački izazovi obrade Rječnika crkvenoslavenskoga... FILOLOGIJA 69(2017), 99-128

Research, EURALEX, 1221-1235.

Wallace, Daniel B. 1996. Greek Grammar Beyond the Basics. An Exegetical Syntax of the New Testament. Grand Rapis, Michigan: Zondervan Publishing House. 827 str.

Turkalj, Lucija. 2012. Sintaksa hrvatskoglagoljskoga psaltira. Doktorski rad. Filozofski fakultet Sveučilišta u Zagrebu. 351 str.

Žagar, Mateo. 2007. Grafolingvistika srednjovjekovnih tekstova. Zagreb: Matica hrvatska. 530 str.

\title{
Microstructure of the Dictionary of the Croatian redaction of Church Slavonic and research challenges in its compiling
}

\begin{abstract}
Dictionary of the Croatian redaction of Church Slavonic is a period dictionary, being the sub-type of the historical dictionary. The paper presents the distinctive feature of the dictionary article, which is containing five idioms and four scripts. The microstructure of the dictionary article, i. e. orthographic, graphic, syntactic, morphological, semantic, stylistic, distibutional, usage, illustrative and interlingual data are presented as well. Owing to the informativeness of its microstructure Dictionary of the Croatian redaction of Church Slavonic enables further non-comparative and comparative given corpus related researches but also serves as a basis for them. The second part of the paper discusses some research challenges in compilling of the Dictionary. They emerge from the fact that the Dictionary is the first lexicographical description of Croatian Church Slavonic, literary idiom with texts translated from Latin and (through Old Church Slavonic tradition) Old Greek originals. As a result, it may happen that a lexicographer sometimes finds the originals more understandable than the translation, which can distract him in making the appropriate identification of the Croatian Church Slavonic entry. Apart from relying to much on the Latin and Old Greek originals, researcher bias can be increased by the influence of synchrony, especially when dealing with entries with recognizable forms and seemingly transparent meanings. Mere awareness of these challenges makes it possible to overcome them, together with the constant deepening of one's linguistic competence and team work.

Ključne riječi: povijesna leksikografija, hrvatski crkvenoslavenski, mikrostruktura rječnika, istraživački izazovi, istraživačka pristranost

Key words: historical lexicography, Croatian Church Slavonic, dictionary's
\end{abstract} microstructure, research challenges, researcher bias ${ }^{21}$

${ }^{21}$ Ovaj rad je financirala Hrvatska zaklada za znanost projektom 2462. 